\title{
The Crowdfund Act's Strange Bedfellows: Democracy and Start-Up Company Investing
}

\author{
John S. Wroldsen ${ }^{*}$
}

\section{INTRODUCTION}

Empowering the masses has a history of launching revolutions. In the 1700s, who would have thought the upstart and inauspicious American democracy would revolutionize politics for centuries? ${ }^{1}$ Yet history has demonstrated that emphasizing equal opportunity for all and relying on the general public's voting decisions proved preferable to aristocratic privilege.

A similar theme of democracy challenging privilege is embodied in the Crowdfund Act. $^{2}$ Before the Crowdfund Act, securities laws gave wealthy, accredited $^{3}$ investors nearly exclusive access to investments in start-up companies. ${ }^{4}$ The Crowdfund Act introduces a democratic paradigm shift by

* Whiting Clinical Fellow, University of Denver Sturm College of Law. The author thanks Brad Bernthal, Patience Crowder, Nathan Chapman, Jim Cox, Kenneth Ching, Skip Eisiminger, Chris Lasch, and Kevin Lynch for helpful comments and discussions. All errors are the author's.

1. E.g., Paul Johnson, A History of the American People 139 (Harper Perennial ed. 1997) (quoting a British "minister in charge of colonial matters" whose "contemptuous view" of democracy characterized the monarchical perspective of the era: "I would not have men in mercantile cast every day collecting themselves together and debating on political matters").

2. See Jumpstart Our Business Startups Act, Pub. L. No. 112-106, 126 Stat. 306 (2012) [hereinafter JOBS Act]. This article uses the term "Crowdfund Act" because it is the name Congress gave to the crowdfunding provisions of the JOBS Act, though the Crowdfund Act is technically Title III of the larger JOBS Act. See generally C. Steven Bradford, The New Federal Crowdfunding Exemption: Promise Unfulfilled, 40 SEC. REg. L.J. 195 (2012) [hereinafter Bradford, The New Federal Crowdfunding Exemption] (providing detailed discussion and analysis of the Crowdfund Act's provisions).

3. 17 C.F.R. $§ 230.501(a)(5)-(6)$ (2013). A natural person qualifies as an accredited investor with (1) an "individual net worth, or joint net worth with that person's spouse, exceed[ing] $\$ 1,000,000$ " excluding that person's primary residence or (2) "an individual income in excess of $\$ 200,000$ in each of the two most recent years or joint income with that person's spouse in excess of $\$ 300,000$ in each of those years and . . . a reasonable expectation of reaching the same income level in the current year." Id.

4. See Usha Rodrigues, Securities Law's Dirty Little Secret, 81 Fordham L. Rev. 3389, 3394, 3396 (2013) ("U.S. securities law has always allowed wealthy investors to enter certain markets (including not only the market for private company investments but also private equity funds and hedge funds), while cordoning off average (retail) investors from the same opportunities.... The logical question ... is why a democratic political system has allowed such unequal treatment to continue."); Zachary J. Gubler, Public Choice Theory and the Private 
inviting all investors to invest in start-up companies that seek funds through Internet crowdfunding. ${ }^{5}$ But democratic revolutions are messy, and it can be tempting to retreat to yesterday's refuge where experts, or in crowdfunding's case, wealthy investors, were almost exclusively in charge. Failing to embrace crowdfunding's democratic promise, though, would be a mistake. This article argues that the Crowdfund Act's democratic intent should be protected and nurtured so that crowdfunding's democratic characteristics have the opportunity to develop and evolve.

Fusing democratic participation and start-up company investing is an uneasy union, as Part II briefly explains. The Crowdfund Act reflects the strain of uniting the competing value systems of democracy, where each citizen has one equal vote, and capitalism (i.e., start-up company investing), where wealthier investors wield greater market power. Part III briefly summarizes the main provisions of the Crowdfund Act. Then, to examine the Crowdfund Act's juxtaposition of democratic values against economic clout proportionate to investors' wealth, Parts IV through VI analyze three areas where the Crowdfund Act alternately incorporates, rejects, and potentially undermines democratic participation.

Part IV compares start-up companies' typical preference for few investors, each of whom invests a lot, with crowdfunding's embrace of many investors, each of whom invests a little. It then considers whether crowdfunded companies, which are by definition small, private enterprises, but which are likely to have hundreds, or even thousands, of investors, should have quasi-public reporting obligations. Such reporting obligations reinforce the democratic spirit of crowdfunding by giving investors in small companies unprecedented statutory information rights. But the obligations must be implemented carefully to avoid over-burdening start-up enterprises.

Part V contrasts venture capitalists' experienced, personal attention to their portfolio investments with the crowd's inexperienced, dispersed monitoring of its investments. It also highlights the differences between investing in a relatively efficient stock market, such as the market for public company stocks with active day trading and extensive analyst coverage, and investing in an inefficient market, such as the market for most start-up company stocks. Part V then argues that the Crowdfund Act should promote

Securities Market, 91 N.C. L. REV. 745, 800 (2013) (observing that "the private securities market represents an entire class of investments that are out of reach for the retail investor"). A small and limited exception is Rule 504 of Regulation D, which allows unaccredited investors with a preexisting relationship with the issuer (i.e., friends and family) to invest up to $\$ 1$ million in a nonpublic offering. See infra note 64 and accompanying text.

5. See JOBS Act sec. 302(a) (allowing investors of any income or net worth level to invest in crowdfunding offerings). 
crowdfunding's democratic characteristic of the wisdom of the crowd and require crowdfunded companies to communicate with potential investors over the Internet. It also investigates whether, as an analog to citizens' ability and responsibility to select and monitor political leaders, ${ }^{6}$ retail investors will be skilled at selecting and monitoring investments in start-up companies.

Part VI examines the Crowdfund Act's investment caps on the amount companies can raise and individuals can invest each year in crowdfunding securities offerings. It then explains how these caps tip the delicate balance between democratic participation and capitalist tendencies too far in favor of capitalism because the caps create the potential for crowdfunded companies and wealthy investors to crowd out lower- to middle-income investors from promising crowdfunding offerings. As a result, Part VI advocates regulations to help the Crowdfund Act deliver on its democratic promise of opening start-up company investing to all Internet investors, without sacrificing crowdfunding's capitalist potential.

\section{CrowdFunding, Democratic PARTiCIPATION, AND CAPITALiSM}

\section{A. Democratic Origins of Crowdfunding}

Crowdfunding means using the Internet to pool financial contributions (usually in small individual amounts) from many people (i.e., the crowd) for a common purpose. ${ }^{7}$ The practice is popular in such diverse areas as raising money in politics, ${ }^{8}$ facilitating person-to-person lending, ${ }^{9}$ donating to nonprofit causes, ${ }^{10}$ and launching creative ventures. ${ }^{11}$ Crowdfunding grew out

6. See, e.g., JAMES SUROWIECKI, THE WiSDOM OF CROWDS: Why the MANY ARE SMARTER than the Few and How COllective Wisdom Shapes Business, ECONOMIES, SOCIETIES, AND NATIONS 22, 224-58, 266-68 (2004) (applying the wisdom of crowds to financial markets and political elections in a representative democracy).

7. See Jeff Howe, Crowdsourcing: Why the Power of the Crowd is Driving the FUTURE OF BUSINESS 247, 253 (hardcover ed. 2008).

8. E.g., Daniel M. Satorius \& Stu Pollard, Crowd Funding: What Independent Producers Should Know About the Legal Pitfalls, 28 ENT. \& SPORTS LAw. 15, 16 (2010) (discussing the use of crowdfunding for President Obama's 2012 campaign).

9. E.g., Eric C. Chaffee \& Geoffrey C. Rapp, Regulating Online Peer-To-Peer Lending in the Aftermath of Dodd-Frank: In Search of an Evolving Regulatory Regime for an Evolving Industry, 69 WASH. \& LeE L. ReV. 485, 501 (2012); Andrew Verstein, The Misregulation of Person-To-Person Lending, 45 U.C. DAVIS L. REV. 445, 447 (2011).

10. E.g., About Us, KIVA, http://www.kiva.org/about (last visited Nov. 15, 2013); Sarah B. Lawsky, Money for Nothing: Charitable Deductions for Microfinance Lenders, 61 SMU L. REv. 1525, 1530-33 (2008).

11. E.g., Our Movement, ROCKETHUB, http://www.rockethub.com/about (last visited Nov. 15, 
of "crowdsourcing,", which, instead of pooling money as in crowdfunding, concentrates collective knowledge on solving problems or accomplishing tasks, thereby celebrating the democratic "wisdom of the crowd" 13 over the specialized knowledge of experts. ${ }^{14}$ The wisdom of the crowd does not imply "that a group will always give you the right answer" but instead means "that on average it will consistently come up with a better answer than any individual could provide." 15

For example, the crowd has resolved scientific puzzles that stumped experts $^{16}$ and has demonstrated its wisdom repeatedly in various computer programming challenges, such as the development of Netflix's movie recommendation algorithm and Linux's open-source software. ${ }^{17}$ The crowd's wisdom is also the backbone of Google's search engine, other Google products and applications, Wikipedia's user-generated encyclopedia, and Amazon's product rating system. ${ }^{18}$ Further, the most accurate prediction markets rely on the wisdom of the crowd, and one of the strongest testaments to the crowd's acumen is the difficulty expert stock traders have in consistently beating the stock market's performance. ${ }^{19}$

2013); Learn How to Raise Money for an Idea, INDIEGOGO, http://www.indiegogo.com/learn-howto-raise-money-for-a-campaign (last visited Nov. 15, 2013); Kickstarter Basics: Kickstarter 101, KICKSTARTER, http://www.kickstarter.com/help/faq/kickstarter\%20basics (last visited Nov. 15, 2013).

12. See Jeff Howe, The Rise of Crowdsourcing, WIRED (June 2006), http://www.wired.com/wired/archive/14.06/crowds.html. Howe's article is one of the first articles, if not the first, to define "crowdsourcing."

13. SUROWIECKI, supra note 6.

14. See generally Howe, supra note 7 (discussing crowdsourcing and providing numerous examples of the wisdom of the crowd); SUROWIECKI, supra note 6 (analyzing the wisdom of the crowd).

15. SUROWIECKI, supra note 6, at 235. But see Adrian Vermeule, Many-Minds Arguments in Legal Theory, 1 J. LEGAL ANALYSIS 1, 7 (2009) (critiquing the wisdom of crowds principle and asserting that "the social psychology literature is on the whole pessimistic about the wisdom of crowds").

16. See, e.g., HowE, supra note 7, at 146-54 (InnoCentive, a network of scientists who solve scientific problems); SUROWIECKI, supra note 6, at 158-61 (successful collaboration of labs worldwide in 2003 by the World Health Organization to find cause of SARS and discovery of "top quark particle" in 1994 by 450 physicists). See generally SUROWIECKI, supra note 6, at 161-72 (explaining the benefits of scientific collaboration).

17. Howe, supra note 7, at 53-54, 155-58. See also, e.g., HowE, supra note 7, at 122-27 (software programming competitions by TopCoder), 135-38 (software programming competitions by Mathworks that allow users to tweak each other's codes).

18. See Howe, supra note 7, at 57-61, 75, 234-37, 279 (providing "a one-word response: Google" to questions about "whether the failure of" some crowdsourcing projects "signifies the failure of crowdsourcing" generally).

19. See HowE, supra note 7, at 160-63, 165-66, 169-73 (discussing accuracy of the Iowa Political Stock Market in predicting election outcomes, the Hewlett-Packard "market" made up of employees who were rewarded by predicting sales, and Marketocracy mock investments); 
Crowdfunding aligns with the Internet phenomena of social networking and viral marketing in that it functions most effectively when many people are connected through a common interest. ${ }^{20}$ Like successful candidates in democratic elections, crowdfunding prowess derives from large numbers of equal followers, not from small groups of influential or wealthy contributors. It is democratic insofar as any idea that captures the attention of the crowd can attract substantial amounts of money, typically in low-dollar contributions from numerous people, similar to how politicians achieve electoral success in a democracy by winning the support of many voters who each casts a single vote.

For example, countless crowdfunding projects have received widespread support from thousands of Internet users. ${ }^{21}$ The campaign to fund the creation of an elevated iPhone dock amassed nearly $\$ 1.5$ million from over 12,500 supporters. $^{22}$ The Project Eternity video game campaign raised almost $\$ 4$ million from nearly 74,000 fans. ${ }^{23}$ The OUYA video game console project collected over $\$ 8.5$ million from more than 63,000 people. ${ }^{24}$ Examples of other, more modest projects include the Reverence photography campaign, which raised $\$ 50,015$ from 210 backers, ${ }^{25}$ and the "self-cleaning fish tank that grows food" project, which received almost $\$ 250,000$ from 4,097 supporters. $^{26}$ One European study found that the median crowdfunding project targets $€ 100,000$ and raises $€ 28,500$. $^{27}$

SUROWIECKI, supra note 6, at 235-36 (asserting that "the fact that only a tiny fraction of investors consistently do better than the market remains the most powerful piece of evidence that the market is efficient"); Miriam A. Cherry \& Robert L. Rogers, Prediction Markets and the First Amendment, 2008 U. ILL. L. REV. 833, 837-40 (2008) (discussing and providing examples of prediction markets).

20. See Ethan Mollick, The Dynamics of Crowdfunding: An Exploratory Study, 29 J. Bus. VENTURING 1, 8 (forthcoming 2014) (correlating the success rate of crowdfunded projects on Kickstarter with the number of Facebook "friends" a project founder has).

21. E.g., Statistics, KIVA, http://www.kiva.org/about/stats (last visited Nov. 15, 2013); Kickstarter Stats, KICKSTARTER, http://www.kickstarter.com/help/stats (last visited Nov. 15, 2013).

22. Casey Hopkins et al., Elevation Dock: The Best Dock for iPhone, KicKSTARTER, http://www.kickstarter.com/projects/hop/elevation-dock-the-best-dock-for-iphone?ref=most-funded (last visited Nov. 15, 2013).

23. Obsidian Entertainment, Project Eternity, KicksTARTER, http://www.kickstarter.com/projects/obsidian/project-eternity?ref=most-funded (last visited Nov. 15, 2013).

24. OUYA, OUYA: A New Kind of Video Game Console, Kickstarter, http://www.kickstarter.com/projects/ouya/ouya-a-new-kind-of-video-game-console?ref=mostfunded (last visited Nov. 15, 2013).

25. Zana Briski, Reverence, KICKSTARTER, http://www.kickstarter.com/projects/1072396487/ reverence-0?ref=most-funded (last visited Nov. 17, 2013).

26. Nikhil \& Alejandro, Home Aquaponics Kit: Self-Cleaning Fish Tank that Grows Food, KICKSTARTER, http://www.kickstarter.com/projects/2142509221/home-aquaponics-kit-self-cleaningfish-tank-that-g?ref=most-funded (last visited Nov. 17, 2013).

27. Armin Schwienbacher \& Benjamin Larralde, Crowdfunding of Small Entrepreneurial 
Prior to the Crowdfund Act, however, securities laws made it difficult for start-up companies to offer their securities to the general public, which effectively prohibited crowdfunding for equity securities in start-up companies. ${ }^{28}$ Instead, start-up companies relied overwhelmingly on Rule 506 of Regulation $\mathrm{D}^{29}$ and offered their securities to accredited investors while excluding the general public from the opportunity to invest in start-up companies, "creating a world divided into investing haves and have-nots" for investments in private companies. ${ }^{30}$ Against this regulatory backdrop,

Ventures, in HANDBooK of ENTREPRENEURIAL FinANCE 369, 371 (Douglas Cumming ed., Oxford Univ. Press 2012).

28. E.g., C. Steven Bradford, Crowdfunding and the Federal Securities Laws, 2012 Colum. Bus. L. REv. 1, 29-45 (2012) [hereinafter Bradford, Crowdfunding and the Federal Securities Laws]. Bradford provides: "Section 5 of the Securities Act and the SEC rules associated with Section 5 are a morass of prohibitions, exceptions, conditions, and exceptions to exceptions .... Offerings of securities must be registered with the SEC unless an exemption is available. Unfortunately, registration is not a viable option for early-stage small businesses seeking relatively small amounts of capital. It is too expensive and too time-consuming for crowdfunded offerings.... Companies selling securities on crowdfunding sites could avoid registration if an exemption were available. Several exemptions might possibly apply.... Unfortunately, none of those exemptions is conducive to crowdfunding." Id. (footnotes omitted). Thomas Lee Hazen, Crowdfunding or Fraudfunding? Social Networks and the Securities Laws-Why the Specially Tailored Exemption Must be Conditioned on Meaningful Disclosure, 90 N.C. L. REV. 1735, 1744-50 (2012). Hazen provides: “. . . prior to the JOBS Act, there were no exemptions from registration that could be used for crowdfunding capital raising without requiring that an offering circular be sent to potential investors prior to their being asked to make an investment decision. However, the SEC already had statutory authority to craft an exemption that could apply to crowdfunding... [T] [Tere were a number of proposals to provide such an exemption, and these proposals led to the JOBS Act." Id. (footnotes omitted). Joan MacLeod Heminway \& Sheldon Ryan Hoffman, Proceed at Your Peril: Crowdfunding and the Securities Act of 1933, 78 TENN. L. REV. 879, 892-907 (2011) (assuming that "crowdfunding interests are securities within the meaning of Section 2(a)(1) of the Securities Act[,] ... crowdfunding websites and crowdfunded ventures [are exposed] to the prospect of regulation-including through the expensive and time-consuming process of registering offers and sales of securities - under the Securities Act" (emphasis added) (footnote omitted)); Nikki D. Pope, Crowdfunding Microstartups: It's Time for the Securities and Exchange Commission to Approve a Small Offering Exemption, 13 U. PA. J. Bus. L. 973, 986-93 (2011) ("The present construction of securities regulations leaves very little room for microstartups to raise capital. What room there is comes at a price that may be too high for entrepreneurs to bear, assuming the entrepreneur can even figure out what she has to do to be in regulatory compliance.").

29. 17 C.F.R. § 230.506 (2008). Offerings under the Rule 506 safe harbor can be for an unlimited dollar amount, must include resale restrictions, and-prior to implementation of the JOBS Act's amendments - must avoid a public solicitation-i.e., the offering must target accredited investors and the issuer must reasonably believe there are no more than thirty-five unaccredited investors. The JOBS Act loosens Rule 506 requirements even further by allowing public solicitations so long as only accredited investors purchase securities in a Rule 506 offering. JOBS Act sec. 201(a)(1).

30. Rodrigues, supra note 4, at 3422. Securities law "discriminates on the basis of wealth, as a proxy for sophistication, or the ability to fend for oneself. Securities law thus in theory, as in practice, marginalizes the average investor...."Id. at 3427. Indeed, one study found that only approximately $15 \%$ of private securities offerings under Regulation D that sought $\$ 5$ million or less included unaccredited investors. Rutheford B. Campbell, Jr., The Wreck of Regulation D: The 
Congress endorsed crowdfunding's democratic character ${ }^{31}$ by granting all investors access to start-up company securities offered through crowdfunding. ${ }^{32}$

Though the Crowdfund Act permits wealthy investors to invest more money than average investors, the Act does not exclude any investors, as even low-income investors are allowed to invest up to $\$ 2,000$ per year in crowdfunded securities offerings. ${ }^{33}$ Thus, like the achievement of universal suffrage in political elections, the Crowdfund Act represents a unique democratic milestone in securities regulation because it opens start-up company investing to the general public, at least in those start-up companies that seek to raise capital through crowdfunding. ${ }^{34}$ But therein lies the rub: whereas other forms of crowdfunding, such as non-profit donations, political fundraising, third-world lending, and artistic support, complement democratic values relatively seamlessly, crowdfunding investment abuts the democratic ethos of the crowd against the competitive forces of capitalist markets.

Accordingly, Congress conditioned the democratic access to crowdfunding investments on numerous investor-protection measures. ${ }^{35}$ It

Unintended (and Bad) Outcomes for the SEC's Crown Jewel Exemptions, 66 Bus. LAW. 919, 930 (2011).

31. E.g., 158 Cong. REC. S1830 (daily ed. Mar. 20, 2012) (statement of Sen. Mary Landrieu) ("We want to make this process more democratic. We want to get out of the secret boardrooms and the private conversations on Wall Street. So many more people could take advantage, appropriately, of exciting investments in the entrepreneurial spirit of America."). For additional discussion of the democratic intent of the Crowdfund Act, see infra Part V.B.

32. JOBS Act sec. 302(a).

33. Id. As discussed in more depth in Part $\mathrm{V}$, the $\$ 2,000$ investment cap applies to anyone with an annual income or net worth between $\$ 0$ and $\$ 40,000$.

34. As discussed in more depth in Part V, the democratic milestone is not absolute insofar as the total amount a company may raise each year through crowdfunding is capped at $\$ 1$ million. JOBS Act sec. 302(a). Therefore, crowdfunding investors will still be excluded from higher dollar offerings made exclusively to venture capital firms. Rodrigues, supra note 4, at 3433-34 ("In other words, even with [the Crowdfund Act], the real home runs are still reserved for the big wallets."). See also John S. Wroldsen, The Social Network and the Crowdfund Act: Zuckerberg, Saverin, and Venture Capitalists' Dilution of the Crowd, 15 VAND. J. ENT. \& TECH. L. 583, 611-12 (2013) (noting that crowdfunding investors are more akin to early-stage angel investors than to venture capitalists that invest larger amounts in later stages of a company's development); Kevin Lawton, Unlocking the Global Trillion-Dollar Crowdfunding Market, VentuREBEAT (Dec. 24, 2012, 2:30 PM), http://venturebeat.com/2012/12/24/crowdfunding-market/ ("Having companies that have been proven out using crowdfunding will only create better pickings for the venture capital industry to come in and scale those startups." (quoting Manu Kumar, K9 Ventures)).

35. See generally Bradford, The New Crowdfunding Exemption, supra note 2 (detailing and analyzing the Crowdfund Act's requirements); Stuart R. Cohn, The New Crowdfunding Registration Exemption: Good Idea, Bad Execution, 64 FLA. L. REV. 1433, 1438-43 (2012) ("Promoters seeking to raise small amounts from small investors are now subject to such a wide range of disclosure and regulatory requirements ...."); Andrew A. Schwartz, Crowdfunding Securities, 88 NotRE DAME L. 
remains an open question whether these measures strike the right regulatory balance of freeing entrepreneurs to raise capital with reasonable oversight or raising the cost of compliance so high that start-up companies decide not to take advantage of crowdfunding. ${ }^{36}$ The open access that crowdfunding promises will be realized in practice only after the Securities and Exchange Commission (the SEC) finalizes the regulations ${ }^{37}$ to implement the numerous details of the Act that Congress left to the SEC's discretion. ${ }^{38}$

\section{B. Capitalist Tensions in Crowdfunding}

Nonetheless, in principle the Crowdfund Act ambitiously unites crowdfunding's popular, democratic character with the capitalist haven of entrepreneurial start-up companies. It is a challenging union. Though the sacrosanct American principles of democracy and capitalism are often intertwined, $^{39}$ the two concepts can be theoretically opposed ${ }^{40}$ and

REv. 1457, 1460-66 (2013) (summarizing the provisions of the Crowdfund Act).

36. Compare Robert B. Thompson \& Donald C. Langevoort, Redrawing the Public-Private Boundaries in Entrepreneurial Capital-Raising 35 (Georgetown Pub. Law \& Legal Theory Research Paper No. 12-119, 2012), available at http://ssrn.com/ abstract=2132813 (noting that due to the Crowdfund Act's "quite heavy and costly set of responsibilities ... it is difficult for us to see why a rational start-up entrepreneur would find it appealing to use the new [crowdfunding] exemption at all"); with Schwartz, supra note 35, at 1473 (concluding that the Crowdfund Act "stands a good chance of lowering the cost of raising relatively small amounts of business capital from the disparate public").

37. The Crowdfund Act set a deadline of January 1, 2013 for the SEC to issue the regulations. JOBS Act sec. 302(c). On October 23, 2013, as this article is going to press, the SEC released proposed regulations with a 90 day comment period. Crowdfunding, 78 Fed. Reg. 66428-01 (proposed Oct. 23, 2013) (to be codified as 17 C.F.R. pts. 200, 227, 232, 239, 240 and 249) http://www.sec.gov/rules/proposed/2013/33-9470.pdf.

38. E.g., JOBS Act sec. 302(b), §§ (a)(12), (b)(5) (authorizing the SEC to require crowdfunding intermediaries - i.e., the websites where crowdfunding investments must occur-and issuers to meet "such other requirements as the Commission may, by rule, prescribe, for the protection of investors and in the public interest").

39. E.g., Donald C. Langevoort \& Robert B. Thompson, "Publicness" in Contemporary Securities Regulation After the JOBS Act, 101 GEO. L.J. 337, 378 (2013) (asserting that "things like transparency, accountability, and openness to external voices are expected of large American corporations" even though these concepts are from "the world more often populated by administrative and constitutional law and political science" and "typically have been characteristics of government"); Adolf A. Berle, JR., The 20th Century Capitalist Revolution 164-88 (1954) (describing corporations' political role in a capitalist society and arguing that democratic principles, such as checks on absolute power, do apply to corporations); MILTON FRIEDMAN, CAPITALISM AND FREEDOM 7-21 (1962) (arguing there is an intimate connection between free market capitalism and democratic political freedom); MiChaEL NOVAK, THE SPIRIT OF DEMOCRATIC CAPITALISM 14 (1982) ("To begin with, modern democracy and modern capitalism proceed from identical historical impulses."). See also UptON SinclaiR, The Jungle (1906) (chronicling unregulated capitalism and corrupt politics prior to anti-trust and other protective laws, and exemplifying how public outcry in a democracy can lead to legal restrictions on corporate behavior, such as the pure food and drug laws enacted in response to Sinclair's exposé). 
practically incompatible ${ }^{41}$ in certain circumstances, as even the United States' founding fathers recognized. ${ }^{42}$ Democracy celebrates individual equality with its one-person-one-vote philosophy while capitalism acceptseven exalts-economic inequality under its "one-dollar-one-vote principle."43 Democracy seeks political stability, balance, and equal rights, where capitalism rewards innovation and successful economic risk-taking, often leading to unpredictable market swings and unequal distributions of wealth. $^{44}$

40. Securities laws seek to balance democratic and capitalist interests. See Langevoort \& Thompson, supra note 39, at 383 (recognizing "the democratic legitimacy of subjecting private institutions to greater public transparency" but cautioning that "this attention [should focus] on the largest of companies," not smaller public companies that cannot bear the costs associated with extensive regulatory requirements); Mark J. Roe, A Political Theory of American Corporate Finance, 91 Colum. L. REV. 10, 66 (1991) ("Concentrated financial capital does not mix well with a broad-based egalitarian democracy in which interest groups can acquire great influence ....”).

41. E.g., Amy Chua, World on Fire: How Exporting Free Market Democracy Breeds ETHNiC HATRED AND Global InSTABiLity, 198 (2003) (asserting that "there is always an inherent instability in free market democracy"). The tension between democracy and capitalism arises, in its most elementary and threatening form, from "the confrontation between market wealth held by a few and democratic power held by the many...." Id. at 190. Thus, "there is always, in any democratic, capitalist society a potential conflict between market-generated wealth disparities and majoritarian politics." Id. See also Richard Stith, If Dorothy Had Not Had Toto to Pull Back the Wizard's Curtain: The Fabrication of Human Rights as a World Religion, 44 VAL. U. L. REV. 847, 850 (2010) (" $[\mathrm{C}]$ apitalism prefers property and commerce rights to be immune to the erratic and redistributive impulses of popular majorities, for the sake of economic predictability and security. Global capitalism is thus fundamentally anti-democratic, preferring uniform rules favoring capital imposed on all nations.").

42. For example, Alexander Hamilton rejected the capitalist principle of one share, one vote because of its undemocratic propensity to allow a few large shareholders to disproportionately control and benefit from the Bank of the United States. Grant M. Hayden \& Matthew T. Bodie, One Share, One Vote and the False Promise of Shareholder Homogeneity, 30 CARDOZO L. REV. 445, 470 (2008) (describing Hamilton's "prudent mean" approach under which a shareholder's "votes-pershare would decrease as the individual shareholder got more and more shares; a shareholder with five shares might get five votes, but a shareholder with 100 shares might only get ten votes").

43. Ha-Joon Chang, 23 Things They Don't Tell You About Capitalism 10 (2010).

44. The strictures of democracy, such as its checks on unilateral power, can hinder the government's response to, and control over, capitalism's endemic business cycles and concomitant economic booms and busts. RICHARD A. POSNER, THE CRISIS OF CAPITALIST DEMOCRACY 386-87 (2010). Posner noted that John Maynard Keynes "correctly impl[ied] that a totalitarian state can control the business cycle more effectively than a democratic one... [which] do[es] not make totalitarianism superior to democracy or suggest that it is more efficient; judging by the communist experience, it is much less efficient, and all in all an odious flop. But democracy does make it difficult ... to control the business cycle without doing long-term economic damage. Accordingly, the United States has an economic history far more spasmodic and cyclical than American political history .... While the U.S. Constitution has proved relatively sturdy and adaptable, it is America's economic life that has been subject to a dynamic of imperial rise and fall ...." Id. (internal citations omitted). However, "[i]t would be quite radical today even to contemplate imposing on the economy the kind of safeguards that the Constitution places on the political system." Id. See also Tim Wu, The Master Switch: The Rise and Fall of Information EMPIRes 301 (2010) (observing that "most influential economic thought, from Smith to Keynes to Schumpeter, accepts as 
Capitalism's risk and reward paradigm is nowhere more apparent than in start-up company investing, where a great majority of companies fail or produce middling returns on investment while a select few companies achieve extraordinary financial success. ${ }^{45}$ This investing reality has led to a hyper-competitive landscape in which relatively small numbers of sophisticated, wealthy investors commit large amounts of money to confidential, heavily-negotiated investments. ${ }^{46}$ In diametric opposition, crowdfunding investment turns the current start-up company investing model on its head by empowering large numbers of unsophisticated, retail investors to commit small amounts of money towards, what are likely to be, non-confidential, non-negotiated investments. ${ }^{47}$

Part III provides a brief overview of the Crowdfund Act and the provisions of the Act on which this article focuses. Then, the remainder of the article explores the clash of democratic and capitalist values in crowdfunding investments in start-up companies.

\section{OVERVIEW OF THE CROWDFUND ACT}

Detailed summaries and analyses of the Crowdfund Act's provisions have been ably set forth elsewhere. ${ }^{48}$ In broad strokes, the Crowdfund Act will allow start-up companies and small businesses to raise up to $\$ 1$ million on a twelve-month rolling basis through online capital campaigns. ${ }^{49}$ Any

intrinsic to a free-market system the ravages of boom and bust"); HYMAN P. MinSKY, STABILIZING AN UNSTABLE ECONOMY 9-10, 100-01, 120, 219-20, 287-88 (1986) (arguing that "market capitalism is both intrinsically unstable" due to speculative financing, among other factors, "and can lead to distasteful distributions of wealth and power"). See also CARMEn M. REINHART \& KENNETH S. Rogoff, This Time is DifFerent: Eight Centuries of FinANCiAl Folly (2009) (chronicling sovereign and private financial crises with a focus on the systemic risks of leverage).

45. Darian M. Ibrahim, The New Exit in Venture Capital, 65 VAND. L. REV. 1, 29 (2012) (recognizing the "ugly truth [] that most start-ups in [a venture capital] fund will produce no return," so the start-ups "doing well must produce more than a three- to four-fold return to make up for the duds") (emphasis added).

46. See, e.g., J.J. Colao, Fred Wilson and the Death of Venture Capital, Forbes (May 8, 2012), http://www.forbes.com/sites/jjcolao/2012/05/08/fred-wilson-and-the-death-of-venture-capital/ (discussing competition in venture capital markets, including competition from crowdfunders); D. Gordon Smith, The Exit Structure of Venture Capital, 53 UCLA L. REv. 315, 337-55 (2005) (examining venture capitalist contractual provisions related to exit events); Ronald J. Gilson, Engineering a Venture Capital Market: Lessons from the American Experience, 55 STAN. L. REV. 1067, 1076-85 (2003) (analyzing venture capitalist contracting practices).

47. See, e.g., Wroldsen, supra note 34 , at 627-28 (discussing the likelihood that nonnegotiated, click-through agreements will become commonplace in crowdfunding investing).

48. See, e.g., Bradford, The New Federal Crowdfunding Exemption, supra note 2.

49. JOBS Act sec. 302(a). 
Internet investor may participate, ${ }^{50}$ but the amount each investor may invest in crowdfunding offerings is capped at an annual amount ranging from $\$ 2,000$ to $\$ 100,000$ depending on the investor's annual income or net worth. ${ }^{51}$ Companies seeking crowdfunding investment may sell any type of security, whether common stock, preferred stock, debentures, or any existing or novel combination thereof-such as "unequity," which is a short-term, profit-sharing interest stripped of corporate governance rights. ${ }^{52}$ Further, companies must disclose certain information about the offering, such as the price and type of securities, ${ }^{53}$ general information about the company and its management, risk factors, and tax returns or financial statements depending on the size of the offering. ${ }^{54}$

All crowdfunding investments must occur online through registered "funding portals" or traditional broker-dealers, not directly between companies and investors. ${ }^{55}$ The funding portals are tasked with a variety of regulatory functions, such as educating investors, providing a platform for crowdfunding transactions, collecting and disseminating information and disclosures, performing background checks, and fulfilling any other requirements the SEC establishes. ${ }^{56}$ The Act restricts marketing of individual crowdfunding offerings to deter aggressive sales tactics. ${ }^{57}$ It also curtails resale of crowdfunded securities for one year other than resale back

50. The Crowdfund Act does, however, prevent investment companies from either investing in or seeking capital through crowdfunding. See James J. Williamson, The JOBS Act and MiddleIncome Investors: Why It Doesn't Go Far Enough, 122 YALE L.J. 2069, 2075-80 (2013) (lamenting that the JOBS Act prohibits mutual funds from investing in crowdfunding offerings, thereby hindering individual investors from diversifying their crowdfunding investments).

51. JOBS Act sec. 302(a).

52. See, e.g., Joan MacLeod Heminway, What Is a Security in the Crowdfunding Era?, 7 ОНIO ST. ENTREPRENEURIAL BUS. L.J. 335, 360-63 (2012) (discussing novel securities and describing unequity interests in the crowdfunding context); Schwartz, supra note 35, at 1482-89 (explaining the benefits to crowdfunded companies of offering debt securities instead of equity interests).

53. See Alan R. Palmiter, Pricing Disclosure: Crowdfunding's Curious Conundrum, 7 ОНІО ST. ENTREPRENEURIAL BUS. L.J. 373, 388-415 (2012) (analyzing pricing mechanisms and liabilities under the Crowdfund Act).

54. JOBS Act sec. 302(b), § (b)(1)(A)-(H).

55. JOBS Act sec. 302(b), § (a), sec. 304. See also Joan MacLeod Heminway, The New Intermediary on the Block: Funding Portals Under the CROWDFUND Act, 13 U.C. DAVIS Bus. L.J. 177 (2013) (explaining and analyzing funding portals); Karina Sigar, Comment, Fret No More: Inapplicability of Crowdfunding Concerns in the Internet Age and the JOBS Act's Safeguards, 64 ADMIN. L. REV. 473, 499-502 (2012) (discussing the role of self-regulatory organizations under the Crowdfund Act).

56. JOBS Act sec. 302(b), § (a)(1)-(10), sec. 304(b), § (80)(A)-(E).

57. JOBS Act sec. 302(b), § (b)(2). See also Douglas S. Ellenoff, Making Crowdfunding Credible, 66 VAND. L. Rev. En BANC 19, 24-25 (2013) (discussing the Act's marketing and investment solicitation restrictions on companies and funding portals). 
to the company, to accredited investors, or to family members. ${ }^{58}$ And it preempts state "blue-sky" regulation of crowdfunding offerings while still providing for both state and federal civil actions. ${ }^{59}$

Beyond the statutory details, though, the Crowdfund Act's key innovation is to invite start-up companies and small businesses to raise capital from the general public, regardless of investors' wealth, knowledge, or investing acumen. As described in Part II, this innovation causes capitalist forces to collide with democratic principles. Parts IV through VI illustrate this collision by providing three examples of the novel securities law issues that arise under the Crowdfund Act due to the merging of democratic participation and capitalist forces in start-up company investing.

\section{INCORPORATING DEMOCRATIC PARTICIPATION: ANNUAL DISCLOSURES}

\section{A. Preference for Few Investors}

An article in a leading entrepreneurship magazine discusses the capitalraising efforts and strategy of one start-up company, Sheex, Inc., which "makes bedding and sleepwear from performance fabric." accurately captures the approach most start-up companies take to financing new ventures: "The rule of thumb when raising funds is, [t]he fewer investors, the better." ${ }^{\text {61 }}$ Such a rule of thumb favors wealthy investors who have more investable funds than less wealthy investors. From a capitalist perspective, the rule of thumb often makes good business sense for start-up companies because, among other reasons, managing relationships with fewer investors involves lower transaction costs. ${ }^{62}$ But from a democratic perspective, the rule of thumb operates to discriminate against less wealthy investors - a start-up company that is motivated to minimize the number of its investors necessarily seeks higher investment amounts from each investor, thereby favoring wealthy investors who can afford to invest more than less wealthy investors. ${ }^{63}$

58. JOBS Act sec. 302(b), § (e)

59. JOBS Act sec. 305; JOBS Act sec. 302(b), § (c).

60. April Joyner, The More, the Merrier? The Benefits and Drawbacks of Having a Laundry List of Investors, INC., July-Aug. 2012, at 92-94.

61. Id. at 92 .

62. See Rodrigues, supra note 4, at 3432 (noting that transaction costs alone would drive firms toward fewer investors, each of whom invests a large amount).

63. See id. at 3413 (noting that "the private market, with its promise of outsized returns, is the exclusive preserve of the accredited investor"). 
Furthermore, securities laws enhance this discrimination by making it much easier for start-up companies to raise funds from wealthy, accredited investors than from less wealthy, retail investors. ${ }^{64}$ In addition to favoring wealthy investors, securities laws also discourage private companies from having a large number of investors. ${ }^{65}$ Securities laws require private companies with more than $\$ 10$ million in assets to comply with certain public company reporting obligations ${ }^{66}$ once the number of the company's shareholders "of record" reaches either 500 unaccredited investors or 2,000 total investors. ${ }^{67}$ Prior to the JOBS Act, the threshold was even lower: reporting obligations were triggered once a company had at least 500 total shareholders of record. ${ }^{68}$

Crowdfunding, however, represents a paradigm shift from the reigning model that encourages start-up companies to have few investors. For example, the Sheex article emphasized that the company founders bucked

64. Though securities laws and regulations did not involve "a conspiracy to keep the average Joe out of the private market," the practical effect has been to favor accredited investors. See Rodrigues, supra note 4, at 3417-22. For example, offerings to accredited investors under Rule 506 can be for an unlimited dollar amount and generally do not require disclosures. 17 C.F.R. $§ 230.506$ (2013). In contrast, offerings to unaccredited investors under Rule 504 can amount to no more than $\$ 1,000,000$ and can only be to people with whom the issuer has a preexisting relationship-e.g., friends and family. 17 C.F.R. $\$ 230.504(b)$ (2013).

65. See William K. Sjostrom, Jr., Questioning the 500 Equity Holder Trigger, 1 HARV. Bus. L. REV. ONLINE 43, 43-44 (2011), available at http://www.hblr.org/?p=1028 (describing how securities law reporting requirements motivated Google and Facebook to go public before they otherwise would have because each company surpassed the 500 shareholders "of record" threshold that was then applicable).

66. Id. (discussing the disclosure and reporting obligations that become applicable once a company surpasses the asset size and shareholder of record thresholds, and concluding that "[b]asically, the company has the same SEC obligations as a public company but does not receive the benefits of going public, principally a large infusion of equity capital and liquidity for its stock").

67. 15 U.S.C. $\$ 78 \mathrm{l}(\mathrm{g})(1)(2012)$. Certain shareholders are not counted as shareholders "of record," such as employees who obtained shares through an employee compensation plan that was exempt from public registration requirements. JOBS Act $\S 502$. Furthermore, the number of shareholders of record often grossly understates the actual number of a company's shareholders. For example, if 100 individual shareholders own shares of a company through the same brokerage firm, or through different brokerage firms that all use the same depository company to hold the shares, then the SEC only counts the brokerage firm, or the depository company, as one shareholder. E.g., Gubler, supra note 4, at 766-68 (discussing the SEC's narrow interpretation of the term "held of record," resulting in each brokerage's depository account, not each beneficial owner, being counted as a shareholder of record); Langevoort \& Thompson, supra note 39, at 349, 355-61 (explaining that the shareholders "of record" measurement has become "disconnected from any economic reality and somewhat manipulable"). The understating of the number of a company's shareholders may be less pronounced in crowdfunding to the extent crowdfunding investors purchase shares directly from the company instead of through brokers because each beneficial owner would be counted as a shareholder of record.

68. See Michael D. Guttentag, Patching a Hole from the JOBS Act: How and Why to Rewrite the Rules that Require Firms to Make Periodic Disclosures, 88 IND. L.J. 151, 164-78 (2013) (chronicling the history of the shareholder of record threshold). 
the trend of preferring few investors by raising $\$ 9.1$ million from 69 investors, marveling that 69 is a large number of investors for a start-up company. ${ }^{69}$ In a successful crowdfunding offering, though, the 69 investors that represented an atypically large number of start-up company investors in Sheex's case could easily increase by several orders of magnitude and become $6,900,69,000$, or even 690,000 or more crowdfunding investors. ${ }^{70}$

For instance, prior to the Crowdfund Act, one U.S. crowdfunding campaign netted pledges from over 5 million people to invest a total of $\$ 200$ million to purchase Pabst Brewing Company, though the SEC required the campaign to close before consummating the transaction because the campaign failed to comply with securities laws. ${ }^{71}$ A different Internet stock offering in the U.S. that did comply with securities laws prior to the Crowdfund Act raised nearly $\$ 2$ million from approximately 3,500 investors. ${ }^{72}$ In the U.K., some 20,000 people contributed approximately $£ 35$ each to raise more than $£ 700,000$ to purchase a professional soccer team. ${ }^{73}$ And in Spain, an international campaign fueled by Twitter helped a Spanish soccer club avoid bankruptcy by raising more than $€ 1.57$ million from over 20,000 new shareholders by selling largely symbolic shares of stock for $€ 10.75$ per share. $^{74}$

Thus, whereas 69 investors may be an abnormally high number of investors for a start-up company that does not rely on crowdfunding, it is merely the tip of the iceberg for successful crowdfunding offerings. Even so, the Sheex example is instructive for crowdfunding offerings because it illustrates the types of legal rights that investors and entrepreneurs negotiate

69. Joyner, supra note 60, at 92 (exclaiming that the Sheex co-founders raised capital "from 69 - yes, 69-investors" while discussing the advantages and disadvantages of raising start-up funds from a large number of investors).

70. See, e.g., supra notes 20-26 and accompanying text (citing examples of the number of participants in non-equity crowdfunding campaigns); infra notes 170-74 and accompanying text (discussing the number of investors in Internet stock offerings).

71. Cease-and-Desist Order for Michael Migliozzi II \& Brian William Flatow, Securities Act Release No. 9216 (June 8, 2011), available at http://www.sec.gov/litigation/admin/2011/339216.pdf.

72. Pope, supra note 28, at 978-79 (explaining that Spring Street Brewing Company's direct public offering was conducted in accordance with Regulation A).

73. Howe, supra note 7 , at 255. See also Society Rules, MYFOOTBALlCLUB, http://www.myfootballclub.co.uk/society-rules (last visited Nov. 14, 2013) (offering each contributor one nontransferable voting share in the entity that owns the EbbsFleet United soccer team, along with information rights to view the team's financial data and the opportunity to become one of the team's seven directors).

74. Ken Belson, Effort to Save Soccer Club Sweeps Globe, N.Y. TiMES (Nov. 15, 2012), http://www.nytimes.com/2012/11/16/sports/soccer/last-ditch-effort-to-save-real-oviedo-soccer-clubsweeps-globe.html. See also Historia, Web Oficial REAL OviEdo, http://www.realoviedo.es/es/elclub/historia/ (last visited Nov. 14, 2013). 
as the number of shareholders increases. Sheex broke with the status quo to have 69 angel investors instead of a handful of venture capitalist investors because the company founders wanted to maintain majority control of the company. ${ }^{75}$ A larger number of angel investors, each of whom invested a lower amount than a venture capitalist would have invested, did not demand the control rights that venture capitalists would have required. ${ }^{76}$ Sheex did agree, however, to provide quarterly business updates to all investors. ${ }^{77}$ And in place of the expertise and hands-on management that venture capitalists would have provided, Sheex recruited a board of advisors to counsel the management team. ${ }^{78}$

The Sheex example helps reveal on a small scale the novel legal issues that the Crowdfund Act is forced to confront on a large scale when bringing the democratic masses of retail investors into the private world of investing in start-up companies. As explained in Part IV.B below, Sheex's commitment to provide quarterly reports to its angel investors is analogous to the Crowdfund Act's unique annual disclosure requirement for crowdfunded start-up companies. Furthermore, Sheex's decision to retain majority control and forego the expertise of venture capitalist experts hints at the possibility that crowdfunded companies could benefit from the insights of many less expert advisors through the wisdom of the crowd, as explored in Part V.

\section{B. Obligations to Many Investors}

The Crowdfund Act includes a unique requirement that crowdfunded companies make ongoing disclosures to crowdfunding investors on at least an annual basis. ${ }^{79}$ Specifically, each year crowdfunded companies must disclose to investors and the SEC a "report[] of the results of [the company's] operations and financial statements . . . subject to such

\footnotetext{
75. Joyner, supra note 60 , at 92 ("Despite the pie's being split into so many slices, [the cofounders] have managed to maintain a majority of their company-50.1 percent to be exact ....").

76. Id. (explaining that "the valuations [the co-founders] were being offered [by the venture capitalists] would force them to surrender control of the business, an outcome [the co-founders] felt wasn't fair to them or their early investors").

77. Id. at 94 .

78. Id.

79. JOBS Act sec. 302(b), § (b)(4). The Commission is directed to determine whether annual or more frequent reports are appropriate and the duration of such ongoing reporting requirement. $I d$. See also Andrew A. Schwartz, Keep It Light, Chairman White: SEC Rulemaking Under the Crowdfund Act, 66 VAND. L. REv. EN BANC, 43, 53-55 (2013) (discussing the frequency of periodic reports and potential termination dates for ongoing disclosures).
} 
exceptions . . . as the [SEC] may establish, by rule. ${ }^{80}$ The Crowdfund Act's ongoing disclosure requirement breaks new ground in regulating the relationship between investors and managers of small companies. No other securities law exemption for start-up companies, and not even the disclosure requirements for a mini-public offering under Regulation $\mathrm{A}$, include an ongoing periodic disclosure requirement. ${ }^{81}$ Before the Crowdfund Act, securities laws required only public companies, or private companies that exceeded the asset-size and shareholders-of-record thresholds discussed above ${ }^{82}$ to provide ongoing periodic reports to shareholders. ${ }^{83}$

The general public's participation in crowdfunding offerings explains why the Crowdfund Act's ongoing disclosure requirement makes sense. The Act anticipates many crowdfunding investors in a crowdfunded company, just as a public company has many investors. Therefore, conceptually it is logical to extend appropriate public company reporting requirements to crowdfunded companies. Of course, though crowdfunded companies may have many shareholders, like public companies, crowdfunded companies are

80. Sec. 302(b), § (b)(4). When a company offers securities through crowdfunding, the company must disclose its financial statements and income tax returns, with varying levels of certifications and audits depending on the amount of money the company seeks to raise. Id. § (b)(1)(D). If the company seeks to raise $\$ 100,000$ or less, the company must disclose its financial statements with certification by the principal executive officer that they are "true and complete in all material respects," as well as the company's income tax returns. Id. § (b)(1)(D)(i). If the company seeks more than $\$ 100,000$ and less than $\$ 500,000$, then it must disclose "financial statements reviewed by a[n] [independent] public accountant"- pursuant to "standards and procedures" that the SEC is instructed to provide. Id. § (b)(1)(D)(ii). If the company seeks more than $\$ 500,000$ - unless the SEC establishes a different amount-it must disclose "audited financial statements." Id. § (b)(1)(D)(iii). Apart from the annual disclosure requirements, at the time of the initial crowdfunding offering companies must make several one-time disclosures. Id. $\S(b)(1)$. The one-time disclosures include straightforward information, such as names and contact information of the company and certain key employees and owners, as well as a "description of the [company's] business," "business plan," "financial condition," and the "intended use of the [investment] proceeds." Id.

81. 17 C.F.R. $\S \S 230.251-.263$ (2013); Jeff Schwartz, The Twilight of Equity Liquidity, 34 CARDOZO L. REV. 531, 566 (2012) (noting that a public offering under Regulation A "does not automatically trigger ongoing reporting obligations"). See also Rodrigues, supra note 4, at 3426 ("[M]andatory disclosure requirements apply to the public markets alone."). But the JOBS Act directs the SEC to create a new regulation for offerings up to $\$ 50$ million-informally known as Regulation A+ because Regulation A offerings are capped at $\$ 5$ million-and grants the SEC discretion to require issuers that rely on Regulation A+ to file periodic disclosures. See JOBS Act sec. 401(b)(2), §§ (2)-(4).

82. See supra notes $66-68$ and accompanying text.

83. Guttentag, supra note 68 , at 162-64. The scope of the periodic disclosure requirements of the Securities Exchange Act of 1934 was limited to "firms with securities traded on a national exchange." Id. at 164. Since 1934, "the criteria used to determine which firms should be required to comply with [ongoing periodic disclosure requirements] have been changed only on rare occasion." Id. at 164-65 (discussing four changes in the criteria since 1934). See also Langevoort \& Thompson, supra note 39, at 344-45 (describing how stocks traded in "over-the-counter (OTC) markets" but not on a national exchange can also be subject to ongoing disclosure obligations). 
small, private enterprises with nowhere near the resources of a public company. ${ }^{84}$ Accordingly, the Crowdfund Act requires only limited annual disclosures; whereas, public companies must comply not only with more detailed annual disclosures, but also with a complex web of ongoing reporting obligations. ${ }^{85}$

The Crowdfund Act also wisely excludes crowdfunding investors from the calculation of the number of shareholders of record. ${ }^{86}$ As a result, a crowdfunded company is not subject to public company reporting obligations if it exceeds 500 unaccredited or 2,000 total shareholders of record through crowdfunding offerings, which many crowdfunded companies are likely to do. Instead, crowdfunded companies simply must continue to comply with the Crowdfund Act's annual disclosure requirement.

The Crowdfund Act's innovation of requiring a private company to provide ongoing disclosures to investors on at least an annual basis is a foreseeable outcome of integrating crowdfunding's democratic characteristic of widespread participation into the private-company realm of start-up company investing. Also, eschewing more onerous public company reporting requirements for the middle ground of one annual disclosure obligation respects a small company's limited resources, while also honoring the importance of providing numerous minority investors with information about the company. ${ }^{87}$ A legal requirement that crowdfunded companies make annual disclosures is also appropriate because crowdfunding investors, due to the small size of each investment, their minority ownership position, and the collective-action problems that arise from the dispersed and

84. See JOBS Act sec. 302(b), § (f)(2). The Crowdfund Act targets small companies. Large companies - those that must "file reports pursuant to section 13 or section $15(\mathrm{~d})$ of the Securities Exchange Act of 1934" - are not eligible to sell securities through crowdfunding. Id.

85. Public companies are subject to many more disclosure requirements than what the Crowdfund Act requires. See generally, Dodd-Frank Wall Street Reform and Consumer Protection Act, Pub. L. No. 111-203, 124 Stat. 1376 (2010) (including numerous requirements); SarbanesOxley Act of 2002, Pub. L. No. 107-204, 116 Stat. 745 (2002) (requiring quarterly and annual reports-Forms 10-Q and 10-K, respectively - and reports triggered by particular corporate eventsForm 8-K - in addition to other requirements); Gubler, supra note 4, at 762-63 (summarizing public company "compliance costs and liability costs"); Schwartz, supra note 81, at 583-90 (providing an overview of the most onerous and costly provisions of the Sarbanes-Oxley Act of 2002 and the Dodd-Frank Wall Street Reform and Consumer Protection Act).

86. JOBS Act sec. 303(a), § (6). In contrast, a private company with assets greater than $\$ 10$ million that sells stock under Regulation D or Regulation A, for instance, will become subject to applicable public company reporting requirements once it exceeds 500 unaccredited or 2,000 total shareholders of record because no exception applies to Regulation D or Regulation A offerings. Id. $\S \S($ A)(i)-(ii).

87. Rodrigues, supra note 4, at 3427 (describing the two "traditional justifications for mandatory disclosure - efficiency in scale and the utility of the public good of information"). 
impersonal nature of crowdfunding, ${ }^{88}$ will likely lack the clout to negotiate appropriate information rights on their own. ${ }^{89}$

Notwithstanding the Crowdfund Act's commendable attempt to balance the democratic interest that many investors have in receiving information against the constraints of a small company's limited resources, the requirement that companies make one annual disclosure to investors might not be the best approach. Instead, a series of less detailed but more frequent disclosures might better serve the interests of investors and be more costeffective for companies to provide. Also, more frequent disclosures would more closely track venture capitalists' start-up company investment strategy of monitoring the progress of a portfolio company through ongoing communication with company management. ${ }^{90}$ Especially if crowdfunding laws incorporate the interactive communication requirement between company management and investors discussed in Part $\mathrm{V}$ below, then a legal requirement of short, simple, and frequent communications over the Internet could be more helpful to investors and more cost-effective for companies than one annual disclosure.

\section{REJECTING DEMOCRATIC PARTICIPATION: WiSDOM OF THE CROWD}

Although the Crowdfund Act sensibly incorporates democratic participation by requiring crowdfunded companies to make ongoing disclosures to crowdfunding investors, the Act misses the opportunity to integrate into crowdfunding investment laws a native democratic virtue of crowdfunding, known as the wisdom of the crowd. ${ }^{91}$ Crowdfunding demands a different regulatory paradigm because the Crowdfund Act introduces open and democratic access into the historically private realm of start-up company investing. Before crowdfunding, the paradigm for

88. Langevoort \& Thompson, supra note 39, at 364 ("Required disclosure is more valuable (and necessary) in the presence of dispersed shareholdings facing a collective-action problem.").

89. See James D. Cox, Premises for Reforming the Regulation of Securities Offerings: An Essay, LAw \& CONTEMP. PROBS., Summer 2000, at 11, 13. Institutional investors have the ability, "through their bargaining power, [to] extract from issuers the information they . . require" to inform their investment decisions, and there is a "greater need for regulatory paternalism" where "the market includes investors who lack the resources effectively to extract from the issuer the type of information that" institutional investors can demand. Id. "Mandatory disclosure thus takes over when self-help is not believed possible." Id. See also Wroldsen, supra note 34, at 614-15 (analyzing leverage imbalances in crowdfunding investment negotiations).

90. See, e.g., Gilson, supra note 46, at 1072-73 (discussing venture capitalists' 'intensive monitoring of the portfolio company's performance").

91. Bradford, The New Federal Crowdfunding Exemption, supra note 2, at 219-20. See also supra note 13 and accompanying text. 
regulating start-up company investments focused on stock offerings either to a small group of friends and family ${ }^{92}$ or to sophisticated venture capitalists that carefully negotiated and monitored their large investments. ${ }^{93}$

But the post-crowdfunding regulatory paradigm must adjust to and account for crowdfunding's revolutionary change that allows start-up companies to offer securities to the general public over the Internetinviting small individual investments from many potentially unsophisticated investors who do not have a preexisting relationship with the issuer. Fortunately, existing crowdfunding and crowdsourcing practices in areas outside of investments in securities have already developed the new regulatory paradigm: reliance on the wisdom of the crowd. ${ }^{94}$ All that is missing is for crowdfunding laws to catch up.

For a while it looked as if the Crowdfund Act would include the wisdom of the crowd in its regulatory approach: a legal requirement aimed at developing the wisdom of the crowd was included in two early crowdfunding bills ${ }^{95}$ that Congress discussed prior to hastily drafting and passing the bill that became the Crowdfund Act. ${ }^{96}$ For example, one of the early bills required funding portals - the websites where crowdfunding investments occur $-{ }^{97}$ to "make[] available ... a method of communication that permits the issuer and investors to communicate with one another,"

92. See 17 C.F.R. $\$ 230.504$ (2013) (allowing "[e]xemption[s] for limited offerings and sales of securities not exceeding $\$ 1,000,000 ")$.

93. See id. $\S 230.506$ (allowing "[e]xemption[s] for limited offers and sales without regard to dollar amount of offering").

94. See Ellenoff, supra note 57, at 24 (noting that "the role of the crowd has been important, active, and lively" in other countries' crowdfunding experiences, according to the owners of crowdfunding sites in the United Kingdom and Australia).

95. Entrepreneur Access to Capital Act, H.R. Res. 2930, 112th Cong. (2011); Democratizing Access to Capital Act of 2011, S. Res. 1791, 112th Cong.

96. See Bradford, The New Federal Crowdfunding Exemption, supra note 2, at 216 (describing the short timeframe in which the Crowdfund Act was passed and noting that many of the provisions that became the Crowdfund Act were not "subjected to committee hearings or markup" and "clearly could have benefited from more thorough consideration and markup").

97. See JOBS Act sec. 302(a), § (6)(C) (mentioning funding portals). See also Heminway, supra note 55 , at 179 . In addition to funding portals, registered brokers are permitted to facilitate crowdfunding investments. Id. This article addresses funding portals' role in crowdfunding investment. The implications of brokers' involvement with crowdfunding, and the potential differences between brokers and funding portals in how each might approach crowdfunding, are beyond the scope of this article. Others have noted, however, that including brokers "raises a serious sales pressure concern - a marginal issuer can find a marginal broker to do cold-call telephone solicitations and invoke the exemption from mandatory disclosure and state regulation. Obviously, this is far distant from the vision said to justify crowdfunding; those cold calls (or e-mail spam) will be exposed to neither a crowd nor much likelihood of any wisdom." Thompson \& Langevoort, supra note 36 , at 36 .

98. Entrepreneur Access to Capital Act, H.R. Res. 2930, 112th Cong. sec. 2(b), § (a)(12) 
such as posting on Internet message boards. ${ }^{99}$ Unfortunately, the bill that became the Crowdfund Act remained silent on an interactive communication requirement, and thus no provision relating to the wisdom of the crowd was included in the Crowdfund Act. ${ }^{100}$

A requirement of Internet dialogue between company management and potential crowdfunding investors would help create a forum for the wisdom of the crowd to probe the merits of a crowdfunding offering. ${ }^{101}$ Such a forum would allow investors themselves to assist the SEC in ferreting out fraudulent offerings and increasing transparency in crowdfunding investments: "[a]n open communications platform will help to prevent fraud by allowing investors with particular knowledge about an offering or an issuer to communicate it to other investors ... [and] will lead to betterinformed investors."102 Indeed, "[d]ialogue . . . has a long pedigree in philosophy as a means to truth," 103 and facilitating dialogue between issuers and investors in crowdfunding should help educate investors, ${ }^{104}$ expose fraud, ${ }^{105}$ and subject issuers to liability ${ }^{106}$ for false or misleading statements.

(2011). See also Bradford, Crowdfunding and the Federal Securities Laws, supra note 28, at 13436 (recommending similar functionality).

99. Bradford, The New Federal Crowdfunding Exemption, supra note 2, at 219-20 (criticizing the Act's failure to include interactive communication requirements that would facilitate development of the wisdom of the crowd).

100. See id. Ironically, the Entrepreneur Access to Capital Act was widely denounced as "lack[ing] ... investor protections." Wroldsen, supra note 34, at 598-99. But when the Senate created its version of a crowdfunding law with more investor protections, it neglected the protection that the Entrepreneur Access to Capital Act had included in the form of an interactive communication tool to aid in developing the wisdom of the crowd. See supra note 99.

101. 158 ConG. REC. S1884-01 (daily ed. Mar. 21, 2012) (statement of Sen. Scott Brown) (arguing that "[a]ll the experts agree that we would need to require an intermediary, say, like an eBay, where the crowd can help identify the good and bad players, the way that eBay uses [sic] identified bad sellers on their [sic] site").

102. Bradford, Crowdfunding and the Federal Securities Laws, supra note 28, at 134.

103. Abner S. Greene, Against Interpretive Obligation (to the Supreme Court), 75 FORDHAM L. REV. 1661, 1665-66 (2006). See also Keith Werhan, The Classical Athenian Ancestry of American Freedom of Speech, 2008 SuP. CT. REV. 293, 325-26 (2008) (footnotes omitted) (recognizing Plato's use of dialogue to challenge assumptions: " $[\mathrm{b}] \mathrm{y}$ the end of the dialogue, Socrates typically had exposed the pretensions of those who had clung dogmatically to conventional wisdom.... Socrates insisted that community leaders allow their beliefs to be tested in adversarial dialogue, and to revise their understanding of the truth if they are refuted. ...").

104. See Bradford, Crowdfunding and the Federal Securities Laws, supra note 28, at 114-15 (recognizing that crowdfunding investment has not been studied exhaustively, but arguing that "unsophisticated crowdfunding investors are likely to become more sophisticated over time" and noting one study that revealed crowdfunders under the interest-bearing loan model "moved from lower-performing loans to loans with a higher rate of return" during a two year period).

105. 158 CONG. REC. S1884-01 (daily ed. Mar. 21, 2012) (statement of Sen. Jeffrey Merkley) (arguing that the twenty-one day offering period, instead of the one day period allowed under a different crowdfunding bill, was necessary to "give time for some sort of feedback loops regarding any sort of fraudulent activity"). 
Admittedly, Internet dialogue by itself has its weaknesses. As even casual Internet users know, inapplicable comments and useless blather proliferate on the Internet. But public discussion is also a hallmark of deliberative democracy ${ }^{107}$ and the belief that "it is members of the general public, not government, who are in a better position to arrive at an objective and fair conclusion as to the merits of any new idea or theory." Furthermore, "[o]ne of the lessons of crowdsourcing is that a diverse group of less-expert decision-makers can often make better choices than an expert working individually." 109 Therefore, "[i]t is at least possible that crowdfunding investors will do a better job compared to venture capitalists and angel investors than their relative lack of sophistication would predict."110 Accordingly, crowdfunding laws should create a framework designed to help provide investors with the opportunity to leverage the

106. The Crowdfund Act expressly provides for liability under section 12 of the Securities Act of 1933 for misstatements and omissions. JOBS Act sec. 302(b), § (c). See generally Commission Guidance on the Use of Company Web Sites, 73 Fed. Reg. 45,862, 45,873 (Aug. 7, 2008) (stating that Internet postings "will not be treated differently from other company statements when it comes to the antifraud provisions of the federal securities laws"); Marc R. Packer, Corporate Governance Feature: Using Social Media Technology in Proxy Solicitations, 13 M \& A LAW. No. 5, May 2009, at 12 (discussing SEC guidance on potential liability resulting from "the application of the federal securities laws to electronic communications").

107. See, e.g., Werhan, supra note 103, at 324 (identifying Justices Holmes, John Stuart Mill, and Pericles as believing "that collective acceptance or rejection of any idea after free debate was the best that any society could do in approximating truth"); Christopher T. Wonnell, Truth and the Marketplace of Ideas, 19 U.C. DAVIS L. REV. 669, 724 (1986) (observing that "there does seem to be reason to hope that a citizenry enriched by the need to make its own practical decisions will develop over time at least a modest critical faculty for evaluating the claims of speakers").

108. Keith Dubick, The Theoretical Foundation for Protecting Freedom of Expression, 13 NAT'L J. CONST. L. 1, 23 (2001) (discussing the marketplace of ideas theory); see also Cathrine Wells Hantzis, Legal Innovation within the Wider Intellectual Tradition: the Pragmatism of Oliver Wendell Holmes, Jr., 82 Nw. U. L. REv. 541, 583, 589 (1988) (noting Justice Holmes's "confidence in the jury rests upon the accumulated experience" of practical people and his "recognition of the legitimacy of an 'external' [as opposed to an insider's] perspective").

109. Bradford, Crowdfunding and the Federal Securities Laws, supra note 28, at 114. See also SUROWIECKI, supra note 6, at xvii ("If you put together a big enough and diverse enough group of people and ask them to 'make decisions affecting matters of general interest,' that group's decisions will, over time, be 'intellectually [superior] to the isolated individual,' no matter how smart or wellinformed he is."); Howe, supra note 7, at 134 (observing that the crowd's results can "seem counterintuitive" and that, "[a]s is often said of Wikipedia, collective intelligence works better in practice than it does in theory").

110. Bradford, Crowdfunding and the Federal Securities Laws, supra note 28, at 114. See also Institutional Limited Partners Must Accept Blame for Poor Long-Term Returns from Venture Capital, Says New Kauffman Report: After Fees and Expenses, Most Investors Will Do Better in Public Markets, EwING MARION KAUfFMAN Foundation (May 7, 2012), http://www.kauffman.org/newsroom/institutional-limited-partners-must-accept-blame-for-poor-longterm-returns-from-venture-capital.aspx ("Over the past decade, public stock markets have outperformed the average venture capital fund and for 15 years, VC funds have failed to return to investors the significant amounts of cash invested, despite high-profile successes ....”). 
wisdom of the crowd in selecting and monitoring start-up company investments.

Though developing the wisdom of the crowd through interactive communication should not be the sole means of protecting crowdfunding investors, crowdfunding laws should not ignore or discard the wisdom of the crowd, which the Crowdfund Act does. Parts V.A and V.B describe the application of the wisdom of the crowd to crowdfunding investments. Then Part V.C discusses why crowdfunding laws should include provisions related to the wisdom of the crowd instead of relying solely on market dynamics to guide the wisdom of the crowd.

This article does not suggest that government-i.e., the SEC-micromanage the actual development of the wisdom of the crowd. The SEC should not prescribe the exact content or frequency of investor or issuer communications or the particular technology used to facilitate interaction. More simply, as explained in Part V.C., this article advocates for crowdfunding laws that create a framework to facilitate market competition between private businesses-i.e., the registered funding portals where crowdfunding investments occur-on the basis of effective incorporation of technology that enhances the wisdom of the crowd. ${ }^{111}$

\section{A. Characteristics of Wise Crowds}

For the wisdom of the crowd to be effective and the crowd's judgment to be accurate, the crowd should possess four characteristics: (1) "diversity of opinion," (2) “independence," (3) "decentralization," and (4) a mechanism for aggregating individual judgments. ${ }^{112}$ The first characteristic, diversity of opinion, ${ }^{113}$ and the third characteristic, decentralization, will likely be true of crowdfunding investors because crowdfunding is open to

111. See FRIEDMAN, supra note 39, at 15 (noting that "a free market does not of course eliminate the need for government" and recognizing that "government is essential both as a forum for determining the 'rules of the game' and as an umpire to interpret and enforce the rules decided on").

112. SUROWIECKI, supra note 6, at 10 (asserting that wise crowds share four characteristics: "diversity of opinion (each person should have some private information, even if it's just an eccentric interpretation of known facts), independence (people's opinions are not determined by the opinions of those around them), decentralization (people are able to specialize and draw on local knowledge), and aggregation (some mechanism exists for turning private judgments into a collective decision)"').

113. Deliberation among groups that lack diversity tends to lead to extremism, not wisdom. Edward L. Glaeser \& Cass R. Sunstein, Extremism and Social Learning, 1 J. LEGAL ANALYSIS 263, 267-70 (2009). To the extent a non-diverse subgroup of the general public represents the only participants in crowdfunding investment, the group's wisdom will be impaired. 
the general public, which is by definition a diverse and decentralized group. The second characteristic, independence, might not always be true of crowdfunding investors because the opinions of some investors will undoubtedly influence the decisions of other investors. A crowd's vulnerability to a herd instinct or "group think" will tend to erode the quality of its decisions, but the possibility that independence may be compromised is not unique to crowdfunding investment, as publicly-traded securities can be similarly affected. ${ }^{114}$ One study of a crowdfunding market for mobile applications (apps) found evidence of rational herding among crowdfunding investors: reputable and experienced investors were the first to invest in successful apps, and less knowledgeable investors (the crowd) tended to follow the lead of more knowledgeable investors. ${ }^{115}$

The fourth characteristic of a wise crowd, aggregation of individual judgments, is often accomplished through market price. In an open market, like the market for publicly-traded securities, the market price is a built-in aggregator of the crowd's wisdom - i.e., the "price discovery" mechanismbecause it represents the price at which sellers and buyers are collectively willing to transact. ${ }^{116}$ But crowdfunded securities, unlike publicly-traded securities, will not be freely tradable in an open market because the Crowdfund Act restricts resale of crowdfunded securities. ${ }^{117}$ Therefore, the price of crowdfunded securities will not automatically reflect the collective judgment of all crowdfunding investors because there will only be one

114. See SUROWIECKI, supra note 6, at 229-30, 249-58 (discussing herd instincts and market hysteria in stock market bubbles and crashes); Thompson \& Langevoort, supra note 36, at 36 (noting that "the wisdom of crowds literature stresses that open communication also has a downside, introducing the risk of contagion of information (or bias) that undermines the 'averaging' effect of many independent beliefs").

115. Keongtae Kim \& Siva Viswanathan, The Experts in the Crowd: The Role of Reputable Investors in a Crowdfunding Market 8 (November 2013) (unpublished manuscript) available at http://papers.ssrn.com/sol3/papers.cfm?abstract_id=2258243 (noting also that the particular crowdfunding market, Appbackr, incentivized early investment by allowing early investors to share in profits before later investors).

116. Cherry \& Rogers, supra note 19, at 838 (noting that a stock price "encodes a significant amount of information" through its aggregating, "price discovery" capabilities).

117. JOBS Act sec. 302(b), § (e). Resale of crowdfunded securities, like resale of other nonpublic securities, may occur through private sales to accredited investors or Qualified Institutional Buyers (QIBs) pursuant to securities law exemptions such as Rule 144 and Rule 144A. See Gubler, supra note 4, at 760 (explaining that "the law surrounding resale of restricted [non-publicly-traded] securities make these securities less freely tradable than securities in the public market"); Elizabeth Pollman, Information Issues on Wall Street 2.0, 161 U. PENN. L. REV. 179, 189-91 (2012) (describing securities law exemptions for resale of non-public securities). With the increasing popularity of secondary market transactions over the Internet, a market for resale of securities of successful crowdfunded companies could develop. See generally id. at 193-202 (explaining the functionality, risks, and benefits of the leading Internet secondary markets, SecondMarket and SharesPost). 
seller, the issuer, and pessimistic investors cannot balance optimistic investors in setting a market price. ${ }^{118}$

One minor caveat is that the Crowdfund Act allows issuers to state "the method for determining the price" of its shares before establishing "the final price" of the crowdfunded shares. ${ }^{119}$ Thus, issuers could conceivably set up a bidding system to let the collective judgment of potential investors influence the final price of the crowdfunded shares, but such a system is not required and may be unduly complex for crowdfunding offerings. As discussed below, however, an open market that automatically aggregates investors' preferences through a stock price is not the only way to aggregate a crowd's wisdom or measure market efficiency. ${ }^{120}$

\section{B. Efficient Markets and Crowdfunding}

The efficient market hypothesis ${ }^{121}$ highlights another important distinction between publicly-traded securities and crowdfunded securities. In an efficient market, such as the market for well-known publicly-traded securities, ${ }^{122}$ information about the issuer is plentiful and market price

118. See SUROWIECKI, supra note 6, at 227-28 (arguing that short-selling-the ability of pessimistic investors to bet on a declining share price-is an important characteristic of accurate price discovery in financial markets); Kevin A. Crisp, Giving Investors Short Shrift: How Short Sale Constraints Decrease Market Efficiency and a Modest Proposal for Letting More Shorts Go Naked, 8 J. BUS. \& SEC. L. 135, 141 (2008) (asserting that "constraints on short sales mute market pessimists so that price inflates above that dictated by the average investor expectation").

119. JOBS Act sec. 302(b), § (b)(1)(G).

120. For instance, websites that facilitate resale of private company stock to sophisticated investors over the Internet provide aggregative services in an attempt to help investors make more informed decisions and more accurately price transactions where few public disclosures are available and few buyers and sellers interact to establish a market price. One of these sites "aggregates information about not only recent trade prices, but also posted interest in future transactions, valuations reflected in third-party research, and 'premoney' valuations in earlier venture capital rounds for the issuer." Langevoort \& Thompson, supra note 39, at 349-50. For in-depth discussions of the emergence and risks of the websites that facilitate these secondary market transactions among sophisticated investors, see Ibrahim, supra note 45, at 15-35, and Pollman, supra note 117 , at 193-221.

121. Troy A. Paredes, Blinded by the Light: Information Overload and its Consequences for Securities Regulation, 81 WASH. U. L. Q. 417, 480-84 (2003) (describing the efficient market hypothesis and its impact on securities laws and regulations); Stephen Choi, Regulating Investors Not Issuers: A Market-Based Proposal, 88 CALIF. L. REV. 279, 302-03 (2000) [hereinafter, Choi, Regulating Investors Not Issuers] (referencing three "versions of the efficient markets hypothesis: the strong version, the semistrong version, and the weak version").

122. Some public markets are more efficient than others. See, e.g., Stephen J. Choi, Company Registration: Toward a Status-Based AntiFraud Regime, 64 U. CHI. L. REV. 567, 578-79 (1997) [hereinafter Choi, Company Registration] (explaining how securities laws "partially take[] into account the range in the efficiency of trading markets for different companies' securities"). 
quickly incorporates investors' reactions to new information. ${ }^{123}$ Data is processed efficiently in large part due to the many investors-retail, professional, and institutional - that follow well-known stocks and the many market analysts and news outlets that continually examine market information related to those stocks. ${ }^{124}$

But the explanatory power of the efficient market hypothesis in public markets decreases when applied to small, start-up companies because there is less information available about start-up companies and fewer market analysts and investors following them. ${ }^{125}$ Prior to crowdfunding investment, stock offerings of start-up companies were typically made only to small groups of sophisticated investors, such as venture capitalists. ${ }^{126}$ And venture capitalists can overcome the general market inefficiencies of investing in start-up company stock through intensive due diligence, research, and personal interaction with company founders. ${ }^{127}$ But crowdfunding opens a new and unique channel for selling stock in start-up companies because crowdfunding sales are not made to small groups of sophisticated investors, but rather to the general public.

Unlike private offerings of start-up company stock to sophisticated venture capitalists, crowdfunding offerings are unregistered "initial public offerings," or "direct public offerings," in the sense that they will be a company's first offering directed to the general public. Of course, a crowdfunding offering will be on a much smaller scale than a registered initial public offering (IPO) of a company whose securities will become publicly traded, ${ }^{128}$ but both types of offerings lack the benefit of an efficient

123. Paredes, supra note 121, at 480; SUROWIECKI, supra note 6, at 253 (describing a study that found that publicly-traded stocks moved "higher in the first fifteen seconds" after a positive report aired on a popular stock market television program and "the number of stock trades sextupled in the first minute").

124. Paredes, supra note 121, at 431-32 ("Realistically, few people expect the 'average' individual investor to focus in any detail on the information that companies disclose. As a practical matter, a company's disclosures are largely 'filtered' through experts-various securities professionals and financial intermediaries - who research and process the information and whose trades and recommendations ultimately set securities prices.").

125. Pollman, supra note 117, at 208-11 (observing that little information is known about earlystage companies that have not attracted much public attention); Gubler, supra note 4, at 798 (noting that "less efficient disclosure leads to less efficient stock prices"); Ibrahim, supra note 45, at 18 (remarking that "[c]ommon stock in start-ups is notoriously difficult to value").

126. Rodrigues, supra note 4, at 3397-98.

127. See supra note 46 and accompanying text.

128. See, e.g., 2012 NAT'L VENTURE CAPITAL ASS'N Y.B. 52 fig. 5.03 [hereinafter NVCA Y.B.], available at http://www.finansedlainnowacji.pl/wp-content/uploads/2012/08/NVCAYearbook-2012.pdf (listing statistics on IPOs from 1985 through 2011, including the median offering amounts, such as $\$ 97$ million in 2011 and $\$ 83$ million in 2010). 
market at the time of the initial public sale. ${ }^{129}$ Apart from the differing size of the offerings, there are at least two other important distinctions between an IPO and a crowdfunding offering. First, a company pursuing an IPO typically has years of operating history for analysts and investors to consider. ${ }^{130}$ Second, a company pursuing an IPO also must fulfill many more disclosure requirements than start-up companies seeking crowdfunding investment. ${ }^{131}$ In addition, after an IPO, a company's securities become publicly traded, so the wisdom of the crowd is automatically aggregated in the company's public market price; whereas, after a public crowdfunding offering, the crowdfunded shares cannot be resold in public markets. Therefore, the crowd's wisdom is not automatically reflected in a market price for crowdfunded shares.

But the analogy to IPOs is helpful because "[i]n many ways the analyst is more indispensable to an issuer in the context of an IPO" than in the context of securities that are already publicly-traded because in an IPO "the public has no baseline from which informed investment decision-making can be made." ${ }^{132}$ If this is true of IPOs, it is even truer of crowdfunding offerings. Crowdfunded public offerings not only confront a similar issue of lacking a base line, or established market price, to assess the value of a company's stock, but crowdfunded companies also disclose less information, will often have less operating history, and might have unproven business models. ${ }^{133}$ Also, crowdfunding offerings suffer the additional problem that there will likely be fewer-or no-analysts covering crowdfunding offerings of small, start-up companies compared to the number of analysts following IPOs. ${ }^{134}$

Fortunately, the wisdom of the crowd holds the potential to emulate the

129. See Cox, supra note 89 , at 16 (categorizing "securities that are not traded in an informationally efficient market" as including those securities offered in "IPOs and [by] small capital reporting companies").

130. See NVCA Y.B., supra note 128, at 52 (listing in figure 5.03 the median age of companies that pursue IPOs from 1985 through 2011, such as 10.3 years, 9.2 years, and 8.2 years in 2009, 2010, and 2011, respectively).

131. Cox, supra note 89 , at 15-16 (discussing the benefits of the "filtration" system that, in an efficient market, benefits all investors, including unsophisticated ones, as analysts fulfill their obligations to review public company offering materials).

132. Herbert S. Wander et. al., Developments in Disclosure: Special Problems in Public Offerings-Forward-Looking Information, Including the Private Securities Litigation Reform Act of 1995, 33 SAN DIEGO L. REV. 1027, 1030 (1996).

133. See NVCA Y.B., supra note 128, at 52 (discussing in figure 5.03 the median size and age of companies pursing an IPO).

134. Choi, Company Registration, supra note 122, at 578, 582-83 (observing that "relatively small, low-market-capitalization companies issue securities that trade in illiquid markets" and "enjoy the attention of only a few analysts, if any"). 
role of market analysts who cover publicly-traded securities. To the extent the wisdom of many crowdfunding investors is effectively organized and aggregated, it should help make the market for crowdfunded securities more efficient. Even though there will not be an open crowdfunding market to automatically aggregate investors' preferences through a stock price, crowdfunding investors should benefit from the Internet community serving as a proxy for financial analysts who follow public companies but neglect small, start-up ventures.

In today's Web 2.0 environment, ${ }^{135}$ an interactive communication tool between issuers and crowdfunding investors would serve a similar purpose to public companies' long-standing practice of discussing the company with market analysts: "[c]ommunication between issuer and analyst serves a significant market function in ensuring dissemination of information to the marketplace."136 Public companies do not merely disclose legally-required, static information; company management also participates in meetings and conference calls where a dialogue can be established between analysts and executives. ${ }^{137}$ In the Web 2.0 world of crowdfunding investment, though, the middleman analyst would be removed and the communication would occur directly—and electronically — between the issuer and crowdfunding investors.

Crowdfunding investors would thus begin to establish a relationship with company management over the Internet. The relationship could be nurtured not only through written dialogue on electronic comment boards but also through Internet video conferencing, among other Internet communication mediums. Relying solely on crowdfunded companies' legally-mandated written disclosures significantly impairs crowdfunding investors' ability to develop the wisdom of the crowd through dialogue and ignores both the Internet's facilitation of inexpensive electronic communications and its Web 2.0 culture.

Furthermore, in traditional start-up company investing, angel investors and venture capitalists emphasize personal relationships and frequent communication with company founders. ${ }^{138}$ Similarly, though the crowd's

135. Chaffee \& Rapp, supra note 9, at 501-02 (contrasting Web 2.0, where Internet users participate in content creation, with Web 1.0 , where Internet users passively consume media); Schwienbacher \& Larralde, supra note 27, at 5-6 (discussing Web 2.0 characteristics).

136. Wander, supra note 132, at 1028.

137. See, e.g., Business Earnings Event Calendar, REUTERS.COM, http://www.reuters.com/finance/markets/conferenceCalls?country=USA\&viewBy=type (last visited Nov. 17, 2013) (providing numerous company conference calls with securities analysts).

138. NVCA Y.B., supra note 128, at 7 ("Venture capital partners become actively engaged with a company, typically taking a board seat. With a startup, daily interaction with the management 
relationship and communication with crowdfunded companies' founders will be of a different nature than that of venture capitalists, ${ }^{139}$ crowdfunding investors should follow the lead of venture capitalists and pursue a communicative relationship with crowdfunded companies. Crowdfunding laws and regulations should help by guiding crowdfunding investment practices toward developing the wisdom of the crowd through organized and aggregated Internet dialogue on the funding portals where crowdfunding investment occurs - indeed, the SEC's proposed regulations include a provision for interactive communication. ${ }^{140}$

As explained below, the funding portals where crowdfunding investments occur are ideally situated to become effective organizers and aggregators of crowdfunding investors' collective judgments - even if those judgments are not reflected in a market price. The wisdom of the crowd is not self-organizing, and absent an automatic aggregator such as market price, the wisdom of the crowd is most effective when it is intentionally directed towards a goal. ${ }^{141}$ Congress lacked the foresight to embrace the Internet's power to facilitate the wisdom of the crowd through investors' own democratic, grass-roots policing of crowdfunding offerings. Nevertheless, the crowdfunding community, and even the SEC, can still capitalize on the potential of the wisdom of the crowd to help make crowdfunding markets more efficient and to spread the regulatory burden to more parties instead of relying solely on the SEC and state regulatory agencies.

\section{Funding Portals' Potential}

Notwithstanding Congress's failure to require a means of Internet dialogue between crowdfunding issuers and investors, the Crowdfund Act does potentially create a framework in which the wisdom of the crowd can

team is common.").

139. The differences include such factors as geographic proximity for venture capitalists versus geographic dispersion for crowdfunders, and venture capitalist control rights versus minority positions of crowdfunders. See generally PAul Gompers \& Josh LERnER, THE Venture CAPITAL CYCLE (2004) (discussing the nature of venture capital investments).

140. Crowdfunding, 78 Fed. Reg. 66428-01 (proposed Oct. 23, 2013) (to be codified as 17 C.F.R. pts. 200, 227, 232, 239, 240 and 249), http://www.sec.gov/rules/proposed/2013/33-9470.pdf.

141. Howe, supra note 7, at 284 ("One of the greatest misapprehensions around crowdsourcing is that the crowd works in isolation. In reality, the most successful crowdsourcing efforts are products of a robust collaboration between the crowd and the individuals guiding them ...."); Chris Wilson, The Wisdom of the Chaperones: Digg, Wikipedia, and the Myth of Web 2.0 Democracy, SLATE (Feb. 22, 2008, 6:11 PM), http://www.slate.com/id/2184487/ (describing the role aggregators and decision-makers play in organizing, monitoring, and directing social media on the Internet). 
develop into an effective monitoring tool for crowdfunding investments. Because crowdfunding investments must occur through registered funding portals or registered brokers, ${ }^{142}$ the portals hold great potential for organizing crowdfunding investment and aggregating the wisdom of the crowd. The framework is enhanced through the Crowdfund Act's requirement of a high degree of cooperation between funding portals and the SEC in regulating crowdfunding investment and through its fostering of competition among funding portals.

Scholars have observed that the Internet offers a means for the SEC to (1) rely on, and even compete with, non-governmental third parties for certain regulatory functions; and (2) create an environment in which such third parties compete with each other for the benefit of investors. ${ }^{143}$ By implementing these observations, the Crowdfund Act appropriately tailors legal requirements to the Internet's technological capabilities. The Crowdfund Act astutely, if incompletely, embraces both market forces and the cooperative and competitive efficiencies of the Internet to help the SEC avoid bearing the full burden of monitoring crowdfunding investment activities. ${ }^{144}$

Funding portals cooperate with the SEC in regulating crowdfunding insofar as they share significant responsibilities in helping the SEC reduce the risk of fraud, provide disclosures to potential investors, and gather and disseminate disclosures from the companies seeking crowdfunding investment. ${ }^{145}$ In addition, as funding portals compete for crowdfunding investment business, the websites that most efficiently accomplish

142. JOBS Act sec. 302(a), § (6)(C). See also supra note 97 (discussing brokers that facilitate crowdfunding investments). See also Heminway, supra note 55, at 193 (describing the requirements of funding portals, as "crowdfunding intermediaries," under the Crowdfund Act).

143. Stephen J. Choi, Gatekeepers and the Internet: Rethinking the Regulation of Small Business Capital Formation, J. SMALl \& EMERGing Bus. L., Summer 1998, at 27, 55 (arguing that "perhaps the greatest impact of the Internet on securities regulation ... is to reduce the distinction between public and private means of protecting investors"); Choi, Regulating Investors Not Issuers, supra note 121, at 331-33 (describing proposals under which issuers choose between competing regulatory systems). See also Robert B. Ahdieh, Dialectical Regulation, 38 ConN. L. REV. 863, 868 (2006) (describing "dialectical regulation" as "intersystemic regulation [i.e.,] cross-jurisdictional interactions characterized by jurisdictional overlap and regulatory dependence"); Robert B. Ahdieh, The Dialectical Regulation of Rule 14A-8: Intersystemic Governance in Corporate Law, 2 J. Bus. \& TECH. L. 165, 170 (2007) (explaining that "dialectical regulation aspires to an integration of regulatory regimes").

144. 158 Cong. ReC. S1,714-02 (daily ed. Mar. 15, 2012) (letter of Mary Schapiro, Securities and Exchange Commission Chairman) (observing that "with Commission oversight, these intermediaries could serve a critical gatekeeper function, running background checks, facilitating small businesses' provision of complete and adequate disclosures to investors, and providing the necessary support for these small businesses").

145. JOBS Act sec. 302(b), § (a). 
regulatory tasks in a user-friendly way will have a competitive advantage, whether through their speed, price, ease-of-use, ability to attract and vet high-quality issuers, or other market-driven criteria. Also, competition among funding portals should lead to effective investor protection because funding portals that fail to protect investors will likely gain less credibility in the market and attract fewer entrepreneurs and investors. ${ }^{146}$ Therefore, due to funding portals' self-interested profit motive and narrow focus on crowdfunding investment, ${ }^{147}$ funding portals will possibly be more attentive to regulating crowdfunding than the "overworked, underfunded"148 SEC could be alone.

Unfortunately, the Crowdfund Act's cooperative and competitive regulatory framework failed to include provisions to foster the development of the wisdom of the crowd. The Crowdfund Act should have required funding portals to provide interactive communication functionality on the websites where investment decisions are made. Funding portals need not create such functionality from scratch because the functionality could be outsourced to existing Internet social media platforms and then integrated into the funding portal website. ${ }^{149}$ Including the functionality on the funding portal website, though, would encourage funding portals to serve as central communication hubs, or aggregators, for discussions related to crowdfunding offerings. ${ }^{150}$

Hopefully the SEC will take advantage of the Crowdfund Act's grant of substantial rulemaking discretion ${ }^{151}$ and require funding portals to create a channel of crowdfunding investment dialogue through the funding portal where people decide to invest or not. At a minimum, consistent with the democratic intent of the Crowdfund Act to give all investors access to

146. Choi, Company Registration, supra note 122, at 585-86 (discussing how "market-based incentives" influence underwriters and other intermediaries in their selection of high- or low-quality issuers, and vice versa).

147. Funding portals may also be registered brokers that do more than just crowdfunding. JOBS Act sec. 302(b), $\S(a)(1)$. The focus of such funding portals will be broader than that of funding portals that only do crowdfunding transactions, but still narrower than the SEC's oversight of all aspects of securities regulation.

148. John C. Coffee, Jr., SEC Enforcement: What Has Gone Wrong?, THE CLS BLUE SKY BLOG (Jan. 2, 2013), http://clsbluesky.law.columbia.edu/2013/01/02/sec-enforcement-what-has-gonewrong/ (suggesting that the SEC "retain private counsel on a contingent-fee basis in those large cases that it cannot staff adequately itself").

149. Sigar, supra note 55, at 489-94 (describing several technology solutions that start-up companies are already designing to enhance the effectiveness of the wisdom of the crowd).

150. Ibrahim, supra note 45, at 37-38 (emphasizing the benefit of a "central site" that "make[s] it easier for buyers and sellers to find one another" and facilitates "efficient price discovery by posting recent buy-sell bids and the latest contract price").

151. See supra notes 37-38. 
crowdfunded securities offerings, the SEC should require funding portals to be open to the public, as the Crowdfund Act did not even include this minimal requirement. ${ }^{152}$ Non-public funding portals are antithetical to open, democratic websites where the wisdom of the crowd develops.

Absent a legal requirement, competitive market forces could motivate some funding portals to provide interactive communication functionality to their users. For instance, funding portals might find that Internet dialogue capabilities attract higher quality issuers and more sophisticated or dedicated investors who value transparency and interactive communication. Also, apart from funding portals, other crowdfunding investment websites might provide opportunities for investors and entrepreneurs to communicate electronically. But these other sites might not even be linked to the funding portals where potential investors make investment decisions, which could reduce their impact and lessen their aggregative potential because the dialogue will likely be dispersed throughout cyberspace in an unorganized manner that does not lead to effective development of the wisdom of the crowd. ${ }^{153}$

In addition, absent a legal requirement, some issuers might decide not to communicate with investors at all-perhaps investors would shun a silent issuer who relied solely on its legally-mandated, static disclosures, but perhaps not. A better approach would incorporate the wisdom of the crowd into the crowdfunding legal framework. Then crowdfunding investors could assess and compare issuers' responses ${ }^{154}$ on the very websites where investment decisions are made. And the crowd could cultivate its wisdom with feedback from issuers in a centralized location where the crowd's wisdom could be usefully aggregated. Incorporating the wisdom of the crowd into crowdfunding investment offerings could also eventually serve as

152. Bradford, The New Federal Crowdfunding Exemption, supra note 2, at 219 ("The new exemption omits a crucial element of crowdfunding - an open, public communications channel allowing potential investors to communicate with the issuer and each other.").

153. Zachary J. Griffin, Note, Crowdfunding: Fleecing the American Masses, _ CASE W. RES. J. L. TECH. \& INTERNET _ (forthcoming 2013) (manuscript at 34-35), available at http://papers.ssrn.com/sol3/papers.cfm?abstract_id=2030001\&download=yes (arguing against the effectiveness of the wisdom of the crowd but noting that its effectiveness in ferreting out fraud depends, in part, on crowdfunding investors being able to see and read information posted by fellow investors).

154. Any legal requirement of interactive communication should avoid unduly burdening startup company management. So long as a reasonableness standard applies to companies' obligations to interact with the crowd, though, it should not be too costly for small companies seeking crowdfunding investment to correspond with, or hold videoconferences for, potential investors from time to time. In typical Web 2.0 fashion, companies that use crowdfunding will likely value correspondence with the crowd and will often view investors as potential customers and promoters with whom they want to establish a relationship. 
a template to be applied to other types of Internet securities offerings. ${ }^{155}$

\section{UNDERMINING DEMOCRATIC PARTICIPATION: INVESTMENT CAPS}

Apart from Congress's failure to incorporate the self-regulating, democratic principle of the wisdom of the crowd, the Crowdfund Act's dual dollar caps on investment amounts potentially undermine crowdfunding's democratic virtue of widespread participation. One of the unintended consequences of the two caps could be to exclude from crowdfunding investments the very group the Crowdfund Act aims to include: nonwealthy, retail investors. The first investment cap is on the aggregate annual amount that a company ${ }^{156}$ is permitted to raise through crowdfunding: $\$ 1$ million in any twelve-month period. ${ }^{157}$ The second cap is on the aggregate annual amount that a person may invest through crowdfunding, varying according to an investor's wealth. ${ }^{158}$

The cap on the amount of each person's annual crowdfunding investments is based on the investor's annual income or net worth. ${ }^{159}$ The cap applies to the investor's aggregate crowdfunding investments, not each separate investment. ${ }^{160}$ As shown in the table below, in any twelve month period, the cap on each investor is either (i) "the greater of $\$ 2,000$ or 5 percent of the annual income or net worth of such investor, as applicable, if either the annual income or the net worth of the investor is less than $\$ 100,000, " 161$ or (ii) "10 percent of the annual income or net worth of such investor, as applicable, not to exceed a maximum aggregate amount sold of $\$ 100,000$, if either the annual income or net worth of the investor is equal to

155. Crowdfunding is a good test case for interactive communication requirements because the wisdom of the crowd is native to crowdfunding and crowdsourcing. But as the Internet continues to influence investing practices, interactive communications over the Internet could become more commonplace with respect to non-crowdfunding investments. For instance, now that the JOBS Act will allow Rule 506 offerings to be made to the general public so long as only accredited investors actually purchase securities in the offerings, a logical expansion of Internet dialogue and reliance on the wisdom of the crowd would be to incorporate them into Rule 506 offerings that are made over the Internet. See supra note 29.

156. Only U.S. start-up companies and small businesses that are not subject to periodic reporting obligations under the Securities Exchange Act of 1934 are eligible to sell securities under the Crowdfund Act. JOBS Act sec. 302(b), § (f).

157. JOBS Act Sec. 302(a), § (6)(A).

158. Id. $\S(6)(\mathrm{B})$.

159. Id. Poor draftsmanship of the per-investor cap provision may lead to confusion of the exact cap that applies in some cases. Bradford, The New Federal Crowdfunding Exemption, supra note 2, at $200-01,216$.

160. JOBS Act Sec. 302(a), § (6)(A)-(B).

161. Id. $\S(6)(\mathrm{B})(\mathrm{i})$. 
or more than $\$ 100,000 ., " 162$

Translating these percentages into whole numbers, Table 1 below shows the dollar amount of the cap that would apply to different investors based on the amount of the investor's annual income or net worth.

Table 1

\begin{tabular}{|l|l|}
\hline \multicolumn{2}{|l|}{ Caps on Crowdfunding Investors } \\
\hline $\begin{array}{l}\text { Annual Income } \\
\text { Or Net Worth }\end{array}$ & $\begin{array}{l}\text { Investment } \\
\text { Cap }\end{array}$ \\
\hline$\$ 0$ & $\$ 2,000$ \\
\hline$\$ 25,000$ & $\$ 2,000$ \\
\hline$\$ 50,000$ & $\$ 2,500$ \\
\hline$\$ 75,000$ & $\$ 3,750$ \\
\hline$\$ 99,999$ & $\$ 4,999$ \\
\hline$\$ 100,001$ & $\$ 10,000$ \\
\hline$\$ 150,000$ & $\$ 15,000$ \\
\hline$\$ 500,000$ & $\$ 50,000$ \\
\hline $\begin{array}{l}\$ 1,000,000 \\
\text { (and above) }\end{array}$ & $\$ 100,000$ \\
\hline
\end{tabular}

The rule is designed to limit the potential losses of investors who would have difficulty bearing the loss of their entire investment, as is likely to occur with some frequency given the failure rate of start-up businesses. ${ }^{163}$ Ironically, there is no analogously paternalistic measure that limits the amount gamblers may put at risk, even in games of pure chance. ${ }^{164}$ Furthermore, as discussed below, the Crowdfund Act's individual investment caps do not fit either the character of crowdfunding or its current practices. They also openly discriminate against investors on the basis of wealth, thereby providing an opportunity for wealthy investors to crowd out

162. Id. $\S(6)(\mathrm{B})(\mathrm{ii})$. The SEC is directed to adjust all dollar caps for inflation at least once every five years. $I d . \S(\mathrm{h})$.

163. See, e.g., Deborah Gage, The Venture Capital Secret: 3 Out of 4 Start-Ups Fail, WaLl ST. J., Sept. 20, 2012, at B.1 (referencing several different measures of the rate of start-up company failure).

164. E.g., Rodrigues, supra note 4, at 3428-29 (“'[G]overnment intervention in this particular market [i.e., risky private securities markets generally] seems unjustifiable for a number of reasons. Focusing on the risks that stocks pose is somewhat inexplicable, given that individuals are free to lose their shirts a variety of ways. People can purchase cars or homes they cannot afford, or gamble away their savings in a casino or on lottery tickets, all without government interference. While it is true that the market might price some buyers out of certain mortgages or car loans, having a market judge that people cannot afford to buy an item is quite different from the government prohibiting them from purchasing it as a matter of law."). 
poorer investors.

\section{A. High Per Person Amounts}

The Crowdfund Act's caps on the amount investors are allowed to invest, both on the low end of inviting the poor to invest up to $\$ 2,000$ and on the high end of authorizing the rich to invest up to $\$ 100,000$, are incongruous with the nature of crowdfunding. ${ }^{165}$ Even the definition of crowdfunding implies a low dollar cap, as the term means leveraging the democratic power of the masses so that many people contribute small amounts—and thereby risk little — to make a large collective impact. ${ }^{166}$

Empirical evidence bears out this meaning. Kiva's tagline is "Empower people around the world with a $\$ 25$ loan," $" 167$ and the average per-person contribution on Kiva appears to be approximately $\$ 40 .{ }^{168}$ During the Senate's debate on crowdfunding investment, one senator cited the crowdfunding campaign to fund the Blue Like Jazz movie and noted that contributions were received "from a pool of 3,000 donors, most of whom donated $\$ 100$ or less." ${ }^{\text {169 }}$ In addition, a sampling of Kickstarter campaign results indicates that the great majority of crowdfunders of non-equity, creative projects contribute less - and usually much less - than $\$ 500 .{ }^{170}$

165. Lina Jasinskaite, Note, The JOBS Act: Does the Income Cap Really Protect Investors?, 90 DENV. U. L. REV. ONLINE 81, 81 (2013) (arguing that "the cap was set too high to serve as an adequate protection for investors").

166. See Crowdfunding: Connecting Investors and Job Creators: Hearing Before the Subcomm. on TARP, Fin. Serv. and Bailouts of Pub. and Private Programs of the H. Comm. on Oversight and Gov. Reform, 112th Cong. 112-118 (2011) (statement of Meredith B. Cross, Director, Division of Corporation Finance, U.S. Securities and Exchange Commission) (defining crowdfunding as "a form of capital raising whereby groups of people pool money, typically comprised of very small individual contributions, to support an effort by others to accomplish a specific goal"). See also 158 CONG. REC. S1764-04 (daily ed. Mar. 19, 2012) (statement of Sen. Harry Reed) (describing crowdfunding as involving "relatively small investments from many individuals through online platforms").

167. KIVA, http://www.kiva.org (last visited Nov. 18, 2013).

168. Statistics, KIVA, http://www.kiva.org/about/stats (last visited Nov. 18, 2013). Although Kiva does not appear to publish average per-user loan amounts, it does state that the average total amount loaned per Kiva user, including re-loaned funds, is \$410.59. Id. Kiva also states that the average number of loans per Kiva user is 10.01. Id. Therefore, as an approximation of the average per-loan amount, dividing $\$ 410.59$ by 10.01 gives $\$ 41.02$ per Kiva loan.

169. 158 Cong. ReC. S1824-02 (daily ed. Mar. 20, 2012) (statement of Sen. Jeffrey Merkley) (stating that crowdfunding investment "enables aspiring entrepreneurs to access investment capital via the Internet from small dollar investors across America").

170. See Discover / Most Funded, KICKSTARTER, http://www.kickstarter.com/discover/mostfunded? (last visited Nov. 18, 2013). Kickstarter does not appear to publish average contribution amounts per contributor. Id. Reviewing the campaign results of successfully funded campaigns reveals, however, that contributions of less than $\$ 500$ are much more frequent than larger contributions. Id. 
And Kickstarter does not even allow contributions in excess of $\$ 10,000{ }^{171}$

But it is possible, and even likely, that people will invest more in a forprofit entity that offers some hope of a monetary return than they would contribute to other causes in which no monetary return is available. But even in the for-profit context, available evidence suggests that the average investment amount will remain substantially lower than the Crowdfund Act's caps. ${ }^{172}$ In 1996, Spring Street Brewing Company's direct public offering over the Internet averaged investments of approximately $\$ 570$ per investor. ${ }^{173}$ The average pledge to Pabst Brewing Company's crowdfunding campaign was approximately $\$ 40$ per investor. ${ }^{174}$ And a French start-up company received average investments of $€ 510$ per investor, with the majority of investors committing the minimum required investment of $€ 300$, to fund the development of a social media website on world travel. ${ }^{175}$ The French start-up company sold shares at a high minimum investment amount because, under French law, it needed to keep the number of shareholders below one hundred. ${ }^{176}$ Absent this legal requirement, the average investment would likely have been even lower, as the majority of investors opted to contribute the minimum amount. ${ }^{177}$

The Crowdfund Act, though, allows even indigent people to invest up to $\$ 2,000$, and the cap quickly increases above $\$ 2,000$ for people with an annual income or net worth above $\$ 40,000{ }^{178}$ It is not clear what justifies a cap that is significantly higher than what past experience suggests is necessary for crowdfunding investment and that far exceeds what most commentators had advocated. ${ }^{179}$ By applying such an incongruously high

171. Mollick, supra note 20, at 6 .

172. See Crowdfunding, TRAMPOLINE SYSTEMS, http://crowdfunding.trampolinesystems.com/ (last visited Nov. 17, 2013) (detailing a large equity crowdfunding effort in the U.K. aiming to raise $£ 1$ million in four crowdfunding investment rounds, exclusively from existing shareholders and "people certified as high net worth individuals or as sophisticated investors," though information about average investment amounts does not appear to be publicly available).

173. Pope, supra note 28 , at $978-79$.

174. Cease-and-Desist Order for Michael Migliozzi II \& Brian William Flatow, supra note 71, at 3 (stating that over $\$ 200$ million total was pledged by more than 5 million people, which makes the average pledge per person approximately $\$ 40)$.

175. Schwienbacher \& Larralde, supra note 27, at 14-16 (describing the Media No Mad campaign for its website, www.benoot.com, and noting that eighty-one investors purchased an average of 1.7 shares each at $€ 300$ per share, with the majority of investors purchasing only one share).

176. Id. at 17 (discussing the impact of French legal requirements on Media No Mad's crowdfunding offering).

177. Id. at $15-16$ (stating "most investors bought only one share," which were $£ 300$ each).

178. See supra Table 1; JOBS Act sec. 302(a), § (6)(B)(i).

179. See, e.g., Bradford, Crowdfunding and the Federal Securities Laws, supra note 28, at 118 
cap, the Crowdfund Act undermines crowdfunding's native virtue of diversifying risk throughout the crowd and unnecessarily increases the amount of each investor's potential risk.

The high per person investment cap is also incongruous with crowdfunding's character because it allows wealthy investors to invest a large portion of the amount, or even the entire amount, that a company is seeking to raise. For instance, a company seeking to raise the maximum annual amount of $\$ 1$ million could be fully funded by ten people, each of whom had an annual income or net worth of at least $\$ 1$ million. If a company wishes to raise that amount — or larger amounts — of money from a group of wealthy investors, it can do so under other exemptions, most likely Rule 506. ${ }^{180}$ Doing so in a crowdfunding offering, though, could eviscerate the crowd from crowdfunding investment, unless protective measures such as those described below are included in crowdfunding regulations. Such protections would become even more important if certain types of investors, such as accredited or institutional investors, are exempted from the $\$ 100,000$ individual investment cap and permitted to invest even higher amounts. ${ }^{181}$

Allowing the capitalist characteristic of start-up companies' typical preference for a few wealthy investors - as described in Part IV-to undermine crowdfunding's democratic virtue of participation by all exemplifies "the corrosive effect of markets on nonmarket norms." the extent capitalist values dominate crowdfunding, the non-market virtue of crowdfunding-i.e., widespread democratic participation-may be

(suggesting annual investment caps of between $\$ 250,000$ and $\$ 500,000$ per year for each company and $\$ 500$ or $2 \%$ of the investor's annual income for each investor); Heminway \& Hoffman, supra note 28 , at 948-49 (stating their belief that companies should be limited to raising an annual amount of " $\$ 100,000, \$ 250,000$, or possibly even lower thresholds," and each investor should be capped at an annual amount of $\$ 100$ or $\$ 250$ "in a single offering or over a specified period, unless the investor is an accredited investor or sophisticated" (footnotes omitted)); Pope, supra note 28, at 996-99 (advocating a per investor limit of $\$ 1,000$ per year without distinction between accredited and unaccredited investors and an annual cap of $\$ 250,000$ for each start-up company, and citing the Sustainable Economies Law Center's proposal of caps at $\$ 100,000$ per company and $\$ 100$ per investor).

180. See supra note 29 and accompanying text.

181. See Ellenoff, supra note 57, at 21-22 (advocating for the Crowdfund Act's investment caps to not apply to "accredited investors and institutional investors").

182. Michael J. Sandel, What Money Can’t Buy: The Moral Limits of Markets 120 , 203 (2012) (arguing that "the marketization of everything means that people of affluence and people of modest means lead increasingly separate lives.... You might call it the skyboxification of American life. It's not good for democracy ..."). Extending this observation to crowdfunding, the marketization of crowdfunding would allow wealthy investors to preempt other investors from participating in crowdfunding, thereby destroying crowdfunding's original democratic character and foreclosing retail investors' opportunity to invest in start-up companies, just as retail investors lacked these opportunities prior to the Crowdfund Act. 
degraded, as has occurred in other markets. ${ }^{183}$ Apart from crowdfunding, retail investors are already "crowded out" of the broader private securities market, which is in stark opposition to "the model of democratic capitalism that has defined [public company investing] for nearly a century."184 Crowdfunding investments must not succumb to the same fate as other private securities investments but instead should retain their democratic character of public participation.

Crowdfunding, and specifically the risk the Crowdfund Act creates of wealthy investors undermining democratic participation in crowdfunding, illustrates the observation that due to "[t]he democratization of technological power... [t]he individual holds more power than at any time in the past century, and literally in the palm of his hand. Whether or not he can hold on to it is another matter." 185 Crowdfunding laws and regulations should be structured to help retail investors hold on to the democratic promise of crowdfunding. Consistent with the idea "that government's only proper role in the market [is] to ensure opportunity, not to favor entrenched interests," crowdfunding laws and regulations should provide all investors with an opportunity to participate in crowdfunding investment offerings and not allow wealthy investors to crowd out retail investors.

As currently structured, the Crowdfund Act's two caps - the \$1 million annual limit on the amount companies can raise and the high amounts wealthy investors may invest (up to $\$ 100,000$ each) - collaborate to favor wealthy investors and potentially exclude other investors. As described in Part IV above, companies' capitalist preference for fewer, wealthier investors is at odds with crowdfunding's democratic nature that thrives on the participation of many people. Yet, also as noted in Part IV, democratic principles of periodic reporting are incorporated into the Crowdfund Act in anticipation of many investors participating in crowdfunding offerings. Similarly, the democratic nature of crowdfunding should guide investment cap rules so that the high investment caps for wealthy investors do not undermine crowdfunding's democratic value of widespread participation.

183. E.g., Wendell Berry, LiFe is a Miracle: An EsSay Against Modern Superstition 51-55 (2000) (discussing how economic values can destroy non-economic values and asserting that "you cannot preserve the traditional rights and liberties of a democracy by the mechanical principles of economic totalitarianism").

184. Gubler, supra note 4 , at 800.

185. WU, supra note 44, at 298.

186. Id. at 309 . 


\section{B. Wealthy Investors and Crowds of Investors}

Both the nature of crowdfunding and the political intent behind the Crowdfund Act indicate that crowdfunding investment offerings should be open to all Internet investors. For example, President Barack Obama explained the purpose of the Crowdfund Act when signing it into law:

Right now, [start-ups and small businesses] can only turn to a limited group of investors - including banks and wealthy individuals - to get funding. Laws that are nearly eight decades old make it impossible for others to invest. But a lot has changed in 80 years, and it's time our laws did as well. Because of [the Crowdfund Act], start-ups and small business will now have access to a big, new pool of potential investors - namely, the American people. For the first time, ordinary Americans will be able to go online and invest in entrepreneurs that they believe in. ${ }^{187}$

The Senate debate on the Crowdfund Act sounded similar themes: "[c]rowdfunding will create a new alternative market for capital formation by allowing every American - regardless of income or wealth - to invest in a start-up or a great idea" and "[it] will allow small businesses to bypass Wall Street and go straight to Main Street for financing." 188 Another senator asserted that the Crowdfund Act should "make the [start-up company investing] process more democratic" 189 and allow "ordinary people, middleclass people [to] get involved in creating wealth through investing, instead of it being a small club of those who may go to the same school or go to the same social events and have the same social network. We want to move beyond that." 190

But the Crowdfund Act's high per person investment caps allow wealthy investors to invest all or a large portion of the amount an issuer of crowdfunded securities seeks to raise. This right for wealthy investors could undermine the democratic intent of the Crowdfund Act; therefore, crowdfunding laws should provide a mechanism for all investors to have the opportunity to participate in crowdfunding offerings without being

187. Barack Obama, President, United States of America, Remarks by the President at JOBS Act Bill Signing (Apr. 5, 2012), available at http://www.whitehouse.gov/the-pressoffice/2012/04/05/remarks-president-jobs-act-bill-signing.

188. 158 Cong. ReC. S2229-01 (daily ed. Mar. 29, 2012) (statement of Sen. Scott Brown). See also 158 CONG. REC. S1884-01 (daily ed. Mar. 21, 2012) (statement of Sen. Scott Brown) (noting that "only very wealthy people in years past have been able to participate in these types of [start-up company stock] offerings").

189. 158 CONG. REC. S1824-02 (daily ed. Mar. 20, 2012) (statement of Sen. Landrieu).

190. 158 CONG. REC. S1776-02 (daily ed. Mar. 19, 2012) (statement of Sen. Landrieu). 
preempted by wealthy investors. As described below, two rules would help address the potential problem of wealthy investors crowding out the crowd.

\section{Prevent High Minimum Investment Amounts}

Under the first rule, crowdfunding laws and regulations should prohibit issuers from setting minimum per-person investment amounts above a de minimis threshold. For instance, a rule of this type would avoid the problem of an issuer setting a minimum investment amount of, say, \$5,000. A $\$ 5,000$ minimum would exclude any investor with an annual income or net worth below $\$ 100,000$ because the Crowdfund Act's cap on such investors is $\$ 4,999 .{ }^{191}$ Companies seeking crowdfunding investment should not be allowed to hijack democratic participation under the Crowdfund Act by excluding investors below a certain annual income or net worth threshold. After all, those very investors were the intended beneficiaries of the Crowdfund Act's innovative approach to opening start-up company investments to the general public.

Although issuers that are starved for capital will likely welcome investment from any investor in any amount, some start-up companies may want to follow the common practice described in Part IV of minimizing the number of investors. Such companies are free to limit the number of investors and set a high minimum investment amount in offerings made under other securities law exemptions, such as Rule 506. ${ }^{192}$ The Crowdfund Act, though, is designed to encourage companies to solicit investors from among the general public, which includes soliciting investment from unsophisticated and unaccredited investors. ${ }^{193}$ But if issuers set high minimum investment amounts, then crowdfunding offerings will, in fact, only be open to wealthy investors. Companies should not be allowed to solicit investments from the democratic masses through crowdfunding only to deny investment access to people whom the Crowdfund Act was intended

191. See supra notes $159-65$ and accompanying text and Table 1 .

192. See supra note 29 and accompanying text. Issuers will have even easier access to accredited investors now that the JOBS Act removes the restriction on general solicitations from Rule 506 offerings while still requiring that purchasers be accredited investors. JOBS Act sec. 201(a)(1). Prior to the JOBS Act's removal of the prohibition against public solicitations in Rule 506 offerings, many websites would pre-qualify investors as accredited and allow issuers to sell securities exclusively to this pre-qualified group under Rule 506, thus avoiding the - now-revisedprohibition on general solicitations. See, e.g., SECONDMARKET, https://www.secondmarket.com (last visited Nov. 17, 2013).

193. See JOBS Act sec. 302(b), § (b)(2) (allowing public solicitation but requiring that issuers advertise crowdfunding offerings only through "notices which direct investors to the funding portal or broker" where the crowdfunded securities are sold). 
to benefit.

Of course, an issuer might have a legitimate business interest in only accepting investments above a de minimis amount, such as $\$ 0.10, \$ 1.00$, $\$ 100$, or even $\$ 500$. Exactly where the SEC sets a minimum investment amount is somewhat arbitrary. ${ }^{194}$ But the highest minimum investment amount that should be allowed is $\$ 2,000$, which is the lowest cap applicable to any crowdfunding investor. ${ }^{195}$ At that threshold, no investor would be legally barred from participating in a crowdfunding offering on the basis of insufficient annual income or net worth.

It would be incongruous, however, to allow issuers to force investors with an annual income or net worth below $\$ 40,000$ to invest at least $\$ 2,000$ when the Crowdfund Act permits such investors to invest at most $\$ 2,000$. Therefore, it would be reasonable to set legal requirements for minimum investment amounts at less than $\$ 2,000$, perhaps $\$ 100$ or $\$ 500$. Issuers could always elect a per investor limit below the legally-mandated minimum offering amount. Whatever the amount, crowdfunded companies should not be allowed to exclude smaller investors in violation of the democratic intent of the Crowdfund Act.

\section{Define Closing and Oversubscription Procedures}

A second, conceptually similar, problem could be resolved by a multipart rule. The Crowdfund Act requires issuers to commit to a target funding amount and a deadline to reach the target amount. ${ }^{196}$ The target funding deadline must be at least twenty-one days - or "other period [that] the [SEC] may establish"- after the beginning of the offering. ${ }^{197}$ But the Crowdfund

194. Reference points from examples mentioned above include approximate average of $\$ 41$ for Kiva loans, less than $\$ 500$ - and in many cases less than $\$ 100$ - for many successful Kickstarter campaigns, \$570 in Spring Street Brewing Company's Internet offering under Regulation A, and $\$ 40$ pledges in the crowdfunding initiative to buy Pabst Brewing Company. See supra notes 170 , 172, 175-76 and accompanying text. This sample is obviously not an exhaustive empirical analysis, which is outside the scope of this article, but the examples do support the fact that crowdfunding, by definition and in practice, involves the pooling of small amounts of money from many people.

195. JOBS Act sec. 302(a), §§ (6)(A)-(B).

196. Id. sec. 302(b), $\S(\mathrm{b})(1)(\mathrm{F})$. The issuer must also provide regular updates on its progress in reaching the target funding amount. $I d$. Investor funds may only be disbursed to companies after the target amount is reached, and the SEC is directed to determine appropriate rules for crowdfunding investors to be allowed to cancel investment commitments. Id. $\S(\mathrm{a})(7)$. The company must also state the price of the securities or "the method for determining the price." $I d . \S(\mathrm{b})(1)(\mathrm{G})$. If the method of determination - but not the actual price - is initially provided, the final price must be disclosed prior to the closing of the offering, and investors must have "a reasonable opportunity to rescind [their] commitment" to invest after learning the final price. Id.

197. Id. $\S(a)(6)$. The twenty-one day waiting period is created by requiring companies to make 
Act is silent on several related details, such as whether an offering closesor may close-immediately upon reaching the target funding amount and how issuers should handle investments that exceed the target funding amount-i.e., over-subscribed offerings.

The following example illustrates the potential problem and this article's proposed solution. If an issuer sets the aggregate target funding amount at $\$ 100,000$, and one investor with an annual income or net worth of at least $\$ 1$ million invests the full $\$ 100,000$ before anyone else invests, then other investors who want to participate could be barred-i.e., one wealthy investor, or a handful of wealthy investors, could crowd out the crowd. But if the offering is not closed-and further investment commitments are not refused - upon reaching the target funding amount, and there is a mechanism for managing oversubscriptions, then other investors will have the opportunity to participate.

To alleviate the potential for smaller investors to be crowded out and to preserve democratic participation in crowdfunding offerings, crowdfunding rules should include three additional provisions regarding investment commitments. First, the issuer should not be allowed to reject investment commitments that are received prior to the closing of the offering. Second, issuers should be required to either accept investment commitments that exceed the target funding amount ${ }^{198}$ or reduce the excess commitments in accordance with a specified formula described below. Third, investors should be allowed to cancel their commitment to invest at any time prior to the closing of the offering. ${ }^{199}$

In addition, once investment commitments reach the target funding amount, the issuer should have the option to provide written notice of its intent to close the offering early-e.g., five business days' prior written

mandatory disclosures available to investors and the SEC at least twenty-one days before consummating sales of any crowdfunded securities. Id.

198. The Crowdfund Act contemplates oversubscriptions insofar as investment proceeds may only be distributed to issuers "when the aggregate capital raised from all investors is equal to or greater than a target offering amount." Id. § (a)(7) (emphasis added). The Senate debate record indicates that oversubscriptions were discussed. See 158 CONG. REC. S1824-02 (daily ed. Mar. 20, 2012) (statement of Sen. Merkley). Senator Merkley illustrates oversubscriptions through the example of a company that seeks: "\$550,000 to do X, when Americans across the country have put forward enough small investments to reach that goal of $\$ 550,000$, the investment would close. But it also allows, if investors decide they are offering more-maybe folks sign up, and they are so excited about this vision, this product, this invention, this strategy, that they say: I am putting up $\$ 750,000$, even though you only asked for $\$ 550,000$ - it would still enable the small company to say: No, we can use that extra $\$ 200,000$, thank you very much, if they should choose to do so." Id.

199. The component of the proposed rule that allows investors to cancel investment commitments aligns with the Crowdfund Act's directive that the SEC implement appropriate rules that "allow all investors to cancel their commitments to invest." Id. sec. 302(b), § (a)(7). 
notice, posted on the funding portal and emailed to all investors who made investment commitments - so long as the offering remains open for at least twenty-one total days. It is true that a consequence of these rules could include creating an incentive for investors not to invest until after a company's target amount is reached. The incentive would arise because rational investors would realize they could not be excluded from an offering that is fully subscribed. Therefore, they might only invest after other investors demonstrate so much interest in an offering that the company exceeds its target funding amount.

To address this potential incentive to invest only after a company reaches the target funding amount, the legal rules, or the company, could give preference to investments made prior to the company reaching its funding goal. For example, investments made after reaching the target amount could be reduced more aggressively through a modified proration calculation. As an alternative, investors who participate after the target amount is reached could be capped at a maximum total ownership amount that ensures they cannot unduly benefit, at the expense of earlier investors, from waiting to invest until after the target amount was reached. This approach would create an incentive to invest early, while at the same time not excluding those who invest late.

A specific example will help show the rule's effect. Suppose a company is seeking a total crowdfunding investment of $\$ 100,000$, and, before the closing of the offering, sixteen people commit to invest a total of $\$ 205,500$. And suppose the sixteen investors' commitments are divided as follows: one person commits to invest $\$ 100,000$; five people commit to invest $\$ 20,000$; five people commit to invest $\$ 1,000$; and five people commit to invest $\$ 100$.

In that case, under this article's proposed rule, the issuer could choose one of two options: the issuer could accept the full $\$ 205,500$, even though it exceeds $\$ 100,000$; or the company could reduce each investment according to a standard formula in order to bring the total investment amount to $\$ 100,000$, while still allowing all investors to participate. ${ }^{200}$ The formula would apply if either (1) the issuer was unwilling to accept investments greater than the target investment amount or (2) the total commitments exceeded the annual cap on issuers of $\$ 1$ million.

The formula could be designed in numerous ways, and issuers could choose among multiple options or design their own formulas. Two

200. Of course, if issuers set a de minimis floor price for the crowdfunded securities, then the number of investors able to participate in the offering will in effect become capped, regardless of the formula used. For example, if issuers will only accept investments of $\$ 10$ or more, then for a $\$ 1$ million offering, no more than 100,000 investors can participate. 
possibilities would be a pro rata calculation or a rolling calculation. The pro rata calculation would reduce each person's investment by the same percentage. The rolling calculation would rank all investment commitments and allow each person to invest the amount of the lowest commitment, then the second lowest commitment, etc., until the full $\$ 100,000$ was filled. The rolling calculation would reduce larger investments more than smaller investments. Using the hypothetical example above, the tables below show the results of both a straight pro rata calculation and a rolling calculation.

Table 2

\begin{tabular}{|l|l|l|l|l|}
\hline \multicolumn{3}{|l|}{ Pro Rata Calculation } \\
\hline $\begin{array}{l}\text { Commitment } \\
\text { Amount } \\
\text { (each investor) }\end{array}$ & $\begin{array}{l}\text { Number } \\
\text { of } \\
\text { Investors }\end{array}$ & $\begin{array}{l}\text { Investment } \\
\text { Amount } \\
\text { (each investor) }\end{array}$ & $\begin{array}{l}\text { Investment } \\
\text { Amount } \\
\text { (all investors) }\end{array}$ & $\begin{array}{l}\text { Amount of } \\
\text { Commitment } \\
\text { Invested } \\
\text { (each investor) }\end{array}$ \\
\hline$\$ 100$ & 5 & $\$ 49$ & $\$ 243$ & $48.66 \%$ \\
\hline$\$ 1,000$ & 5 & $\$ 487$ & $\$ 2,433$ & $48.66 \%$ \\
\hline$\$ 20,000$ & 5 & $\$ 9,732$ & $\$ 48,662$ & $48.66 \%$ \\
\hline$\$ 100,000$ & 1 & $\$ 48,662$ & $\$ 48,662$ & $48.66 \%$ \\
\hline $\begin{array}{l}\$ 205,500 \\
\text { (total) }\end{array}$ & $\begin{array}{l}16 \\
\text { (total) }\end{array}$ & - & $\begin{array}{l}\$ 100,000 \\
\text { (total) }\end{array}$ & - \\
\hline
\end{tabular}

Under the pro rata calculation in the table above, each person's investment is $48.66 \%$ of the person's commitment. In contrast, under the rolling calculation shown in the table below, the investors who commit lower amounts invest the full amount, or a greater percentage, of their commitment. Correspondingly, the investors who commit higher amounts invest a lower percentage of their commitment.

Table 3

\begin{tabular}{|l|l|l|l|l|}
\hline \multicolumn{2}{|l|}{ Rolling Calculation } \\
\hline $\begin{array}{l}\text { Commitment } \\
\text { Amount } \\
\text { (each investor) }\end{array}$ & $\begin{array}{l}\text { Number of } \\
\text { Investors }\end{array}$ & $\begin{array}{l}\text { Investment } \\
\text { Amount } \\
\text { (each investor) }\end{array}$ & $\begin{array}{l}\text { Investment } \\
\text { Amount } \\
\text { (all investors) }\end{array}$ & $\begin{array}{l}\text { Amount of } \\
\text { Commitment } \\
\text { Invested } \\
\text { (each investor) }\end{array}$ \\
\hline$\$ 100$ & 5 & $\$ 100$ & $\$ 500$ & $100 \%$ \\
\hline$\$ 1,000$ & 5 & $\$ 1,000$ & $\$ 5,000$ & $100 \%$ \\
\hline$\$ 20,000$ & 5 & $\$ 15,750$ & $\$ 78,750$ & $78.75 \%$ \\
\hline$\$ 100,000$ & 1 & $\$ 15,750$ & $\$ 15,750$ & $15.75 \%$ \\
\hline $\begin{array}{l}\$ 205,500 \\
\text { (total) }\end{array}$ & $\begin{array}{l}16 \\
\text { (total) }\end{array}$ & - & $\begin{array}{l}\$ 100,000 \\
\text { (total) }\end{array}$ & - \\
\hline
\end{tabular}


Under both calculations, sixteen people invest an aggregate of $\$ 100,000$. Under the pro rata calculation, $48.66 \%$ of the amount of all commitments is invested. But under the rolling calculation, $100 \%$ of each $\$ 100$ and $\$ 1,000$ commitment is invested. Then, under the rolling calculation, $78.75 \%$ of each $\$ 20,000$ commitment is invested, and $15.75 \%$ of the $\$ 100,000$ commitment is invested. Regardless of which formula is used, the rule honors the democratic spirit of the Crowdfund Act by giving all investors, irrespective of income or net worth, an opportunity to participate in crowdfunded securities offerings.

\section{CONCLUSION}

Internet crowdfunding developed as a grass-roots, democratic movement for activities like non-profit fundraising, financing creative ideas, and peer-to-peer lending. As the Crowdfund Act legalizes crowdfunding investment in start-up companies, though, crowdfunding's democratic ethos intrudes on capitalism's domain of start-up company investing-just as the capitalist forces of start-up company investing collide with democratic participation in crowdfunding. This article analyzed three examples to illustrate how the Crowdfund Act alternately incorporates, rejects, and potentially undermines democratic participation in its attempt to unite crowdfunding and start-up company investing.

The first example showed that notwithstanding the small size of crowdfunded companies, the Crowdfund Act incorporates the democratically-oriented principle of requiring annual disclosures to crowdfunding investors. This is a sensibly unique requirement because crowdfunded companies are likely to have many investors, like a public company. One potential improvement on the annual disclosure requirement could be to require more frequent, but less detailed, electronic communications to complement the interactive nature of Web 2.0 Internet culture and foster the development of the wisdom of the crowd.

The article's second example demonstrated how the Crowdfund Act fails to incorporate an important democratic characteristic of crowdfunding: the wisdom of the crowd. The Crowdfund Act does not require a mechanism of electronic communication between investors and companies seeking crowdfunding investment. The omission is short-sighted because it fails to take advantage of the technological capabilities that the Internet offers to improve the SEC's cooperation with non-governmental regulators-i.e., crowdfunding investors themselves. Accordingly, the SEC's crowdfunding regulations, or a Congressional amendment to the Crowdfund Act, should require funding portals to make this functionality 
available on the websites where crowdfunding investment decisions are made.

Finally, the article's third example highlighted an area where market forces could undermine democratic participation in crowdfunding. The Crowdfund Act's high caps on the amount individual investors may invest through crowdfunding create the potential for retail investors to be crowded out of promising crowdfunding offerings. In view of the Crowdfund Act's ambitious, democratic promise of opening start-up company investing to the general public, crowdfunding regulations should (1) prohibit issuers from setting high minimum investment amounts that bar lower-income investors from participating in crowdfunding offerings and (2) establish clear procedures for closing crowdfunding offerings and pro rating oversubscriptions so that all investors have an opportunity to participate in crowdfunding investment offerings.

In principle, crowdfunding laws and regulations should protect and nurture crowdfunding's democratic ethos of open access for all in order for the Crowdfund Act to deliver on its dual innovation of granting the general public access to investments in start-up companies and granting start-up companies access to funds from the general public. 